\title{
Wokół zmian nazewnictwa ulic na Ziemiach Zachodnich i Północnych po 1945 r. - wybrane aspekty
}

MARIA WAGIŃSKA-MARZEC

Instytut Zachodni im. Zygmunta Wojciechowskiego w Poznaniu

\section{ROCZNIK}

\section{ZIEM}

\section{ZACHODNICH}

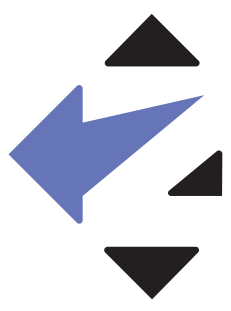




\section{WPROWADZENIE}

\section{Rola nazw - ich funkcja praktyczna i symboliczna}

Wszelkie zmiany w nazewnictwie ulic i placów wiążą się, podobnie jak zmiany nazw geograficznych, ze zjawiskiem przemian polityczno-ustrojowych w państwie. Są narzucane przez władze bądź są efektem żądań społeczeństwa, które chce zamanifestować swój stosunek do teraźniejszości, jak też do przeszłości. Nazwy ulic i placów są zatem - jak zauważyła Anna Pawlikowska-Piechotka - „dokumentem historii miasta, odzwierciedleniem rzeczywistości, jaka jest udziałem jego mieszkańców"1. Burzliwe dzieje narodu powodowały, że nazwy ulic ulegały często wielokrotnym zmianom $\mathrm{w}$ różnych okresach historycznych; a najczęstszym powodem tych zmian były względy polityczno-ideologiczne.

Marta Jankowska, zajmując się problemem zmian imiennictwa ulic, zwróciła uwagę, iż nazewnictwo ulic staje się „swoistym zwierciadłem, w którym odbija się oblicze danego okresu historycznego. Im częstsze zmiany nazewnictwa danej ulicy, tym bardziej burzliwe jego dzieje” ${ }^{2}$. „Ulice porządkują przestrzeń miejską, a ich nazwy są nieodłącznym elementem naszego codziennego życia", zauważyła z kolei Barbara Kasprzyk ${ }^{3}$. Nazwy ulic nie tylko ułatwiają orientację $w$ terenie i identyfikację miejsc, ale też utrwalają w świadomości mieszkańców określone wydarzenia, osoby bądź zjawiska, którym patronują. Dla każdej władzy mają zatem ogromne znaczenie, gdyż odwołują się do określonej symboliki kryjącej się za danymi postaciami czy wydarzeniami. Oprócz funkcji czysto praktycznej nazwy zawierają też w sobie głębszy przekaz; są nośnikiem określonych treści historycznych, kulturowych, społecznych, a także obrazem danego czasu. Z tego właśnie powodu wybór konkretnej nazwy jest skomplikowany i wywołuje niemało emocji, stwierdza Barbara Kasprzyk ${ }^{4}$.

Sytuacja po 1945 r. na ziemiach zachodniej i północnej Polski była pod tym względem szczególna. Obszary te musiały otrzymać zupełnie nową tożsamość i temu celowi podporządkowanych było wiele działań natury zarówno politycznej, jak i czysto administracyjnej. Również przemianowanie nazw (miast, miasteczek, wsi, a także ulic, placów, obiektów fizjograficznych, etc.) nie mogło być przypadkowe; musiały

1 A. Pawlikowska-Piechotka, Nazwy ulic i placów - dziedzictwo kulturowe i dokument historii (na przykładzie Żoliborza urzędniczego w Warszawie, 1916-1995), „Ochrona Zabytków”, nr 49/4 (195), (1996), s. 424.

2 M. Jankowska, Administracyjno-prawna problematyka zmiany nazewnictwa ulic Wrocławia w latach 1945-1946, s. 85, http://www.bibliotekacyfrowa.pl/Content/42784/02_Marta_Jankowska.pdf (dostęp: 23 I 2017 r.).

3 B. Kasprzyk, Kamila Kędziora - „Nazewnictwo ulic Wrocławia w latach 1945-1994”, https://histmag. org/Kamila-Kedziora-Nazewnictwo-ulic-Wroclawia-w-latach-1945-1994-recenzja-7261 (dostęp: 4 XII 2012 r.). 
być one przemyślane i dobrane szczególnie starannie. Chodziło nie tylko o nadanie im polskiego brzmienia, ale też konkretnego wydźwięku, zgodnego z obowiązującą ideologią. Nowe nazwy miały być w tym wypadku uzewnętrznieniem ideologii odpowiadającej duchowi władzy ludowej; musiały być zatem „poprawne” ideologicznie; miały służyć podbudowaniu i legitymizowaniu komunistycznych władz.

Istnieje już całkiem spora literatura dotycząca problematyki nazewnictwa ulic w okresie powojennym, zwłaszcza w odniesieniu do ulic Wrocławia ${ }^{5}$. Bogaty materiał dotyczący skomplikowanego procesu zmian nazw ulic wrocławskich dostarcza zwłaszcza jedna z prac autorstwa Kamili Kędziory, która podjęła się opracowania tej problematyki w ramach pracy magisterskiej. Za główny cel badań postawiła sobie nie tylko ukazanie procesu nadawania nowego imiennictwa ulicom Wrocławia po wojnie, ale podjęła też próbę wyjaśnienia przyczyn wyboru danej nazwy, określenia jej charakteru i lokalizacji miejsca, które miała ona wyznaczać. W dotychczasowej, dość pokaźnej literaturze dotyczącej tej problematyki w powojennym Wrocławiu, jej praca jest szczególnie cenna, gdyż przedstawia kolejne etapy wprowadzania zmian, a także podłoże ideologiczne towarzyszące każdorazowo temu zjawisku, jak również uzależnienie od konkretnych wydarzeń politycznych.

W ciągu ostatnich kilkudziesięciu lat ukazało się też wiele artykułów i opracowań dotyczących problematyki zmiany imiennictwa ulic po $1945 \mathrm{r}$. w odniesieniu do innych, większych (i mniejszych) miast i miejscowości na obszarze Ziem Zachodnich i Północnych; można tu wymienić zarówno opracowania naukowe, jak i zestawienia (słowniki, spisy) nazw ulic (polskich i niemieckich) m.in. Zielonej Góry6,

5 Można wymienić m.in.: W. Taszycki, Nazwy wrocławskich dzielnic i przedmieść, [w:] Rozprawy i studia polonistyczne, t. 1, Wrocław-Warszawa-Kraków 1958; J. Domański, Nazwy miejscowe dzisiejszego Wrocławia i dawnego okręgu wrocławskiego, Warszawa 1967; Z. Antkowiak, Ulice i place Wrocławia, Wrocław 1970; idem, Stare i nowe osiedla Wrocławia, Wrocław 1973; idem, Patroni ulic Wrocławia, Wrocław 1982; F. Nieckula, Niech nazwy mówia!, [w:] Nazwy ulic Wrocławia, red. B. Jancewicz, L. Smołka, Wrocław 2000; E. Kobel, Patroni wrocławskich ulic, placów i zaułków, Wrocław 2008; R. Łobodzińska, Nazwy ulic Wrocławia z perspektywy prac Komisji Nazewnictwa Ulic TMW, [w:] Przeszłość, teraźniejszość i przyszłość polskiej onomastyki, red. R. Łobodzińska, Wrocław 2003; Nazwy ulic Wrocławia, red. B. Jancewicz L. Smołka Wrocław 2000; K. Kędziora, Nazewnictwo ulic Wrocławia w latach 1945-1994, Wrocław 2012; T. Kruszewski, Richard Wagner $i$ jego opery w nazwach ulic Berlina $i$ Wrocławia, Wrocław 2008, i in. Powstały też wydawnictwa słownikowe, m.in. T. Kruszewski, Niemiecko-polski spis ulic, placów i mostów Wrocławia 1873-1993, Wrocław 1993 (II wyd. poprawione i uzupełnione, Wrocław 1997, III wyd. 2001).

6 W. Myszkiewicz, Ulice Zielonej Góry, [w:] Wokół niemieckiego dziedzictwa kulturowego na Ziemiach Zachodnich i Północnych, red. Z. Mazur, Poznań 1997, s. 433-471; zob. też I. Juraszek-Ryś, Jak powstały nowe nazwy ulic w powojennej Zielonej Górze?, „Poznańskie Studia Polonistyczne”, Seria Językoznawcza, t. 19 (39), z. 1, s. 159-171; zob. też Spis nowomianowanych ulic miasta [w] Zielonej Górze (1945), w zbiorach Archiwum Państwowego w Zielonej Górze; por. Ulice. Spis nowo mianowanych ulic miasta [w] Zielonej Górze, „Dumne miano Pionier Zielonej Góry”, kwartalnik, wrzesień 1966. 
Olsztyna $^{7}$, Szczecina $^{8}$, Opola $^{9}$, Elbląga $^{10}$, Legnicy ${ }^{11}$, Białogardu $^{12}$. Są to jednak prace o charakterze wycinkowym, fragmentarycznym, wskazujące jedynie na niektóre aspekty zmian $\mathrm{w}$ nazewnictwie ulic po wojnie $\mathrm{w}$ danej miejscowości; większość z nich to rozprawy ukazujące tę problematykę z punktu widzenia głównie toponomastycznego, historycznego, etymologicznego, językoznawczego czy też administracyjno-prawnego; nie ujmują one całości zagadnienia w sposób kompleksowy. Cenne źródło do badań stanowią zwłaszcza spisy i wykazy nazw ulic z okresu powojennego bądź to zawarte $\mathrm{w}$ monografiach poszczególnych miast, bądź to występujące w rozproszonych materiałach archiwalnych w Archiwach Państwowych na terenie Ziem Zachodnich i Północnych, m.in. Gorzowa ${ }^{13}$, Międzyrzecza ${ }^{14}$, Mrągowa $^{15}$, Słubic ${ }^{16}$ i in..$^{17}$

Celem niniejszego opracowania będzie prześledzenie procesu spolszczania nazw ulic na Ziemiach Zachodnich i Północnych po 1945 r., z uwzględnieniem miasta Łodzi (ze względu na jego specyfikę i podobieństwo praktyk stosowanych na obszarze Ziem Zachodnich i Północnych). Moim zadaniem będzie próba zaprezentowania tego zjawiska przede wszystkim z punktu widzenia społeczno-politycznego,

$7 \quad$ Zob. m.in. S. Piechocki, Alfabetyczny spis niemieckich i polskich nazw ulic, placów oraz mostów Olsztyna, [w:] A. Wakar, Olsztyn. Dzieje miasta, Olsztyn 1997; zob. też M. Biolik, Typy semantyczne współczesnych nazw ulic i placów Olsztyna, „Komunikaty Mazursko-Warmińskie”, nr 1-2, 51-61 (1982), s. 51-61 Wykaz nazw ulic z lat 1892-1945 i ich obecne polskie nazwy (Olsztyn), za: http://www.trzeciarzesza.info/ wykaz-nazw-ulic-z-lat-1892-1945-i-ich-obecne-polskie-nazwy-olsztyn-r170.htm (dostęp: 11 X 2017 r.).

8 Zob. m.in. T. Białecki, Nazewnictwo geograficzne miasta Szczecina, Szczecin 1970; idem, Zmiany topograficzne i onomastyczne Starego Miasta w Szczecinie na przestrzeni dziejów, „Przegląd Zachodniopomorski", nr 3 (1986); idem, Zmiany w nazewnictwie geograficznym Szczecina po 1945 roku, Szczecin 1995; A. Belchnerowska, T. Białecki, Toponimia miasta Szczecina, Szczecin 1988.

9 Zob. m.in. Ł. Jarczak, O powojennych zmianach nazw ulic w Opolu, Opole 2007; M. Choroś, Ł. Jarczak Ludzie i historia w nazwach ulic Opola, Opole 2010

10 W. Engler, Słownik nazw ulic Elbląga, Elbląg 2008.

11 J.M. Juniszewski, Nazwy ulic i placów Legnicy, Legnica 2000.

12 A. Chludziński, Nazwy ulic Białogardu, czesść I: A-Ó, „Przeglad Zachodniopomorski”, (2003), z. 4, s. 173-208, zob. też idem, Nazwy ulic Białogardu, część II: P-Ż, „Przegląd Zachodniopomorski”, (2004), z. 1, s. $109-141$

13 Zob. m.in. Straßenverzeichnis, [w:] Landsberg an der Warthe 1257-1945-1976. Stadt und Land im Umbruch der Zeiten, red. H. Beske, E. Handke, Bielefeld 1976.

14 Zob. np. Spis ulic miasta Międzyrzecza, Zarząd Miejski w Międzyrzeczu, ze zbiorów Muzeum w Międzyrzeczu; "Informator”. Dokumentacja nadzoru budowlanego miasta Międzyrzecza 1887-1944, oprac. F. Relis, T. Kuciak, Szczecin 1988, ze zbiorów Archiwum Państwowego w Szczecinie, Oddz. w Gorzowie Wlkp.

15 Zob. Obecne i byłe nazwy ulic Mragowa, za: http://www.it.mragowo.pl/obecne-i-byle-nazwy-ulice-mragowa,3,2807,pl.html (dostęp: 12 X 2017).

16 Zob. Inwentarz Zespołu Arch. Miasta Frankfurtu n. Odrą 1849-1944, Skorowidz ulic (polskich i niemieckich) w: Protokoły posiedzeń Prezydium Miejskiej Rady Narodowej w Słubicach, 1948 r., nr zesp. 260.

17 Zob. m.in. wykazy i spisy niemieckich i polskich nazw ulic w: Pile, Krośnie Odrzańskim, Świebodzinie, Słupsku, Gubinie etc. 
z uwzględnieniem aspektu ideologicznego. Punktem wyjścia będzie zaprezentowanie zasad i zaleceń względem nadawania nowego nazewnictwa ulic, opartych na naukowych przesłankach, wypracowanych przez Instytut Zachodni, jak również działań podejmowanych w tym kierunku przez administrację państwową. Likwidowanie śladów niemczyzny w nazwach ulic poprzez nadanie im polskiego brzmienia zostanie pokazane na przykładzie kilku wybranych miast, co pozwoli na wskazanie cech charakterystycznych i prawidłowości towarzyszących temu procesowi.

Ze względu na ramy opracowania nie sposób omówić w nim procesu zmian imiennictwa ulic na całym obszarze Ziem Zachodnich i Północnych, toteż niniejsze rozważania ograniczę do kilku wybranych przykładów (większych i mniejszych) miast i miasteczek różnych regionów Ziem Zachodnich i Północnych, aby zasygnalizować różne jego aspekty i najważniejsze cechy; będą to: Wrocław, Gdańsk, Zielona Góra, Świdnica, Bytom, Legnica, Będzin, Reszel, Maszewo. Przykłady te można by naturalnie rozszerzyć o inne, ważne aglomeracje na dawnych terenach niemieckich na wschód od Odry i Nysy Łużyckiej, takie jak Szczecin czy Olsztyn, co mogłoby dopełnić obraz całości, jednak z uwagi na rozmiary niniejszego tekstu zostały tutaj pominięte (mogą stać się tematem odrębnej rozprawy). W opracowaniu pokazano również, w jaki sposób przemianowane zostały niektóre „obowiązkowe” nazwy niemieckie istniejące w niemal każdej miejscowości na omawianym obszarze, nadane uprzednio na cześć przywódców III Rzeszy bądź postaci zasłużonych dla państwa pruskiego.

Podstawę analizy będą stanowiły wykazy (zestawienia, spisy) nazw ulic po $1945 \mathrm{r}$. w różnych (większych i mniejszych) miejscowościach, zawierające nazwy polskie i niemieckie (niekiedy z odniesieniem do ich wcześniejszych postaci w różnych okresach historycznych, a także późniejszych zmian). Oprócz prac zwartych, artykułów i opracowań opublikowanych w czasopismach naukowych, w tekście uwzględnione zostaną też rozproszone materiały, udostępnione drogą internetową przez pasjonatów historii danej miejscowości oraz osoby zajmujące się tą problematyką z zamiłowania. Metoda analizy dokumentów i wykazów nazw w poszczególnych miastach pozwoli na ustalenie, na zasadzie porównawczej, pewnych prawidłowości związanych z tym procesem.

Ramy czasowe opracowania będą obejmowały przede wszystkim lata 1945-1947, z krótkim zarysowaniem zmian w nazewnictwie ulic w okresie III Rzeszy oraz nawiązaniem (w niektórych przypadkach) do współczesnych odpowiedników nazw, aby pokazać, jaką ewolucję przechodziły niekiedy nazwy ulic zmieniane kilkakrotnie również w okresie powojennym.

\section{Germanizacja nazw przed wojną}

Aby lepiej zrozumieć działania związane ze zmianą nazewnictwa ulic w okresie powojennym, należy cofnąć się do historii z lat 30. XX w., by unaocznić podjęte wówczas na masową skalę akcje mające na celu nadanie miastom zdecydowanie „germańskiego" oblicza. Przejęcie władzy w Niemczech przez narodowych socjalistów (30 stycznia 1933 r.) pociągnęło za sobą wiele zmian w życiu politycznym, społecznym i kulturalnym Niemiec w okresie III Rzeszy. Jednym z tego przejawów było przeprowadzenie niemal natychmiast zasadniczych zmian w zakresie nazewnictwa ulic, placów, 
dzielnic oraz rozmaitych obiektów miejskich. Zjawisko to omówił szczegółowo w swej rozprawie Tomasz Kruszewski na przykładzie Wrocławia ${ }^{18}$. We wszystkich tych działaniach widać było przede wszystkim dążenie do publicznego uczczenia osób i kwestii związanych z ideologią nazistowską i usunięcie z nomenklatury miejskiej Wrocławia wszelkich treści, które naziści uznawali za „niegodne” uczczenia.

W pierwszej kolejności był to zatem rozrachunek z siłami lewicowymi (z dziedzictwem socjaldemokratycznym i komunistycznym) oraz tzw. żydostwem i wprowadzenie do publicznego obiegu nazw, które uważano za istotne. Likwidowanie nazw obarczonych tymi treściami miało miejsce zwłaszcza w okresie 1933-193619. Dalszy etap zmian związany był z usuwaniem nazw miejscowych o wyraźnie słowiańskiej proweniencji; punkt kulminacyjny ich germanizacji przypadał na lata 1936-1939. Głównym inicjatorem i wyjątkowo gorliwym wykonawcą tego zadania był ówczesny gauleiter i nadprezydent Śląska, Josef Wagner ${ }^{20}$. Zapoczątkował on też wielką akcję likwidacji wszystkich nazw wskazujących na pochodzenie ziemi śląskiej, wprowadzając w ich miejsce nazwy „czysto” germańskie. Wybuch II wojny światowej spowodował ograniczenie zmian w nazwach ulic, co było wynikiem częściowo tego, że większość z nich została już zmieniona, a częściowo tego, że działania wojenne zmieniły zasadniczo priorytety i sprawa nazewnictwa ulic zeszła na plan dalszy. Niemniej jednak proces germanizacji nazewnictwa miejskiego toczył się nadal w związku z nadawaniem nazw nowo projektowanym ulicom i osiedlom; dokonywano też zmian innych nazw geograficznych wynikających ze zmiany nazw miejscowości bądź osiedli, przeprowadzanych według zasad hitlerowskiej polityki nazewniczej.

\section{ZAKOŃCZENIE WOJNY (1945) - NOWE WYZWANIA}

\section{Zalecenia Instytutu Zachodniego}

Kwestia zmiany nazewnictwa ulic stała się, ze względów chociażby czysto praktycznych, jednym z najbardziej palących problemów do rozwiązania w większości miast na Ziemiach Zachodnich i Północnych. Pierwsze działania w tym kierunku tworzącej się na tych terenach polskiej administracji zostały podjęte stosunkowo wcześnie; można to zilustrować na kilku przykładach.

28 czerwca 1945 r. naczelnik Wydziału Kultury i Sztuki w Koszalinie Stanisław Czapelski rozesłał do wszystkich referentów kultury i sztuki przy Pełnomocniku Rządu RP na Okręg Pomorze Zachodnie pismo wraz z załączonym do niego projektem przemianowania ulic, opracowanym przez Instytut Zachodni; chodziło o zapoznanie się z nim komisji zajmujących się zmianą nazw ulic w miastach na terenie okręgu. Przesłany w załączeniu „Projekt zmian ulic w miastach ziem odzyskanych”

18 Zob. szerzej T. Kruszewski, Zmiany nazw ulic we Wrocławiu w latach Trzeciej Rzeszy, „Studia nad Faszyzmem i Zbrodniami Hitlerowskimi" XIX, Wrocław 1996, s. 243-270.

19 Moc prawną uzyskiwały nowe nazwy z chwilą ich ogłoszenia w dzienniku urzędowym rejencji wrocławskiej („Amtsblatt der Preußischen Regierung in Breslau”). 
(Pomorza, d. Provinz Posen - Westpreussen i Brandenburgii) nosił datę 12 czerwca 1945 r. i został podpisany przez dra Zdzisława Rajewskiego z ramienia Instytutu Zachodniego w Lesznie ${ }^{21}$.

Wspomniany dokument jest jednym z nielicznych zachowanych, wskazujących na pewne ogólne zasady nadawania nazw ulic w kompleksie miejskim i zawiera konkretne wytyczne, jakimi należało się kierować podczas ich przemianowania na obszarze miast przyłączonych do Polski po $1945 \mathrm{r}$. Z tego też względu zasługuje na szersze omówienie. Zwraca się w nim uwagę, iż przy dokonywaniu zmian należy najpierw podzielić miasto na dzielnice nie naruszając tzw. starego miasta, gdyż „Dzielnica staromiejska posiada z reguły ulice o nazwach historycznych, sięgających w głąb średniowiecza i przejętych $\mathrm{w}$ grodach stołecznych z okresu wczesnodziejowego t.j. z czasów pierwszych Piastów"22. Dalej wymieniono w nim tradycyjne, historyczne nazwy ulic występujących w obrębie starego miasta od wieków, co było związane z umiejscowieniem w tym rejonie niektórych pracowni grup rzemieślniczych (stąd nazwy ulic: Szewska, Kowalska, Sukiennicza, Woźna, Złotnicza, Rzeźnicka, etc.); istotny był ponadto układ przestrzenny (w centrum znajdował się na ogół zamek (stąd ulice: Zamkowa, Książęca, Grodzka); w obrębie starego miasta mieściły się też klasztory (stąd ulice: Klasztorna, Cysterska, Benedyktyńska, Franciszkańska, etc.); były ponadto: bramy i baszty (a więc ul. Bramna); mieszkała też służba książęca (a zatem ul. Rybaki, Winiary, Piekary); typowe były też ulice: Jaskółcza, Gołębia, Kozia, etc.

W wypadku ulic starego miasta o „historycznym” brzmieniu obowiązywać miała więc zasada, aby ich w żadnym wypadku nie przemianowywać, a jedynie dokonać pewnych przesunięć, aby „wyrugować z nich nawet cień nazwy niemieckiej”. I tu podano kilka przykładów: np. ul. Farną zmienić na Kościelną, Garbarską - Garbary (Gärber) na Skórnicką, względnie Skórniczą lub Skórników. Należało zachować brzmienie ulic: Piekary, Rybaki, Winiary. Dopuszczalne było też zachowanie ul. św. Wojciecha. Natomiast, gdyby w obrębie Starówki były nazwy ulic książąt lub wodzów niemieckich, to należało je bezwzględnie zmienić (według podanego typu nazw ulic, np. rzemieślniczych).

Postulowano, aby dla upamiętnienia zaginionej w ciągu IX-XIII w. zachodniej Słowiańszczyzny stworzyć specjalną dzielnicę $\mathrm{z}$ nazwami ulic dawnych jej plemion - Obotrytów, Lutyków, Chyżan, Wkrzanów, Hobolan, Ranów, Wagrów, Stodoran, Milczan, Ratarów, Zarowian, Wilków, Lubuszan, Goleszyn i in., i połączyć ją z dzielnicą „żyjącej” Słowiańszczyzny - Łużyczan, Czeską, Morawską, Słowacką, Serbską, Chorwacką, Bułgarską, Ruską, Rosyjską. W opinii badaczy do dzielnicy tej znakomicie nawiązywałyby z kolei dzielnica ziem polskich z nazwami typu: ul. Pomorska, Kaszubska, Kujawska, Wielkopolska, Pałucka, Mazowiecka, Śląska, Małopolska, Podlaska, Podhalańska, „ciesząc przybyszów z wszystkich ziem polskich”. Podobną rolę odgrywałaby dzielnica z nazwami wywodzącymi się od nazw miast polskich - Warszawska, Krakowska, Poznańska, Wrocławska, Szczecińska itd. 
Natomiast dzielnica reprezentacyjna powinna skupiać nazwy Piastów, książąt pomorskich i wielkopolskich, a także niektórych książąt - „naczelników plemion zachodniej Słowiańszczyzny”, m.in. Mieszka I, Bolesława Chrobrego, Krzywoustego, Władysława Łokietka, Kazimierza Wielkiego. Można wymienić jeszcze inne propozycje, jakie padały $w$ kontekście upamiętnienia postaci wybitnych książąt, jak: Ks. Kaźka Szczecińskiego, Ks. Jaromira Rugijskiego, Ks. Bogusława Pomorskiego, Ks. Warcisława Pomorskiego, Ks. Sambora Gdańskiego, Ks. Mestwina Pomorskiego, Ks. Świętopełka Pomorskiego, ul. Przemysława Wielkopolskiego, Ks. Jaksy i in. Uważano, iż dobrze korespondowałaby ta dzielnica z dzielnicą naszych królów i wodzów, np. Władysława Jagiełły, Królowej Jadwigi, Kazimierza Jagiellończyka, Zygmunta Starego, Zygmunta Augusta, Władysława IV, Jana Sobieskiego, Jana Chodkiewicza, Hetmana Żółkiewskiego, Hetmana Tarnowskiego, Jana Zamoyskiego, Stefana Czarnieckiego, Tadeusza Kościuszki, Jana Henryka Dąbrowskiego, Ludwika Mierosławskiego, Romualda Traugutta, Gen. Wybickiego etc. Z tego wynika, że duży nacisk kładziono na aspekt historyczny i odwoływanie się do chlubnych kart historii Polski.

Badacze sugerowali ponadto nazwanie dzielnic od nazwisk zasłużonych kronikarzy i uczonych (np. Wincentego Kadłubka, Janka z Czarnkowa, Jana Długosza, Mikołaja Kopernika, a także badaczy Słowiańszczyzny i Słowiańszczyzny Zachodniej: Wilhelma Bogusławskiego, Oskara Kolberga, Zoriana Dołęgi Chodakowskiego, Samuela Bogumiła Lindego, Joachima Lelewela, Aleksandra Brücknera, Ks. Kujota, Wojciecha Kętrzyńskiego, braci Śniadeckich, Marii Curie-Skłodowskiej, Oswalda Balzera, Władysława Konopczyńskiego, Władysława Smoleńskiego i in.

Miały też powstać dzielnice muzyków, pisarzy i literatów (w tym również ważnych dla danego regionu pisarzy i poetów), a także dzielnice malarzy i rzeźbiarzy, a nawet odkrywców i podróżników. Postulowano stworzenie dzielnic zasłużonych mężów stanu, publicystów i działaczy społecznych: (Górków, Pawła z Włodkowic, Opalińskich, Frycza Modrzewskiego, Staszica, Kołłątaja, Bolesława Limanowskiego, Hipolita Cegielskiego i in., a przede wszystkim - ks. Bolesława Domańskiego (prezesa Związku Polaków w Niemczech). Nie mogło zabraknąć dzielnicy sportowej w pobliżu boisk oraz dzielnicy kwiatów i drzew w części willowej. Poza tym jako ulice rozgraniczające dzielnice sugerowano, aby znalazły się ulice: np. Grunwaldzka, Hołdu Pruskiego, 3 Maja, a także - Stalina, Roosevelta, ul. Sprzymierzonych etc. Postulowano, by w celu lepszej orientacji ulice wylotowe nazwać mianem większych miast, do których prowadzą.

W dokumencie zawarto też szereg wskazówek dotyczących błędów, których należało unikać przy opracowywaniu imiennictwa miejskiego, m.in. nazwy placu pochodzenia niemieckiego; w to miejsce należało stosować określenia „Błonia” lub „Błonie”, np. Błonie Moniuszki, Błonie Sprzymierzonych, Błonie Piastowskie, Wojska Polskiego, Armii Radzieckiej etc. Gdyby nie udało się zastosować nazwy „błonie”, wówczas należało użyć określenia „Rynek”²3. Unikać należało również nazwy „park” (jako nazwy obcej) w odniesieniu do ogrodów; w to miejsce należało zastosować nazwę „Ogród” 
wraz z nazwą dzielnicy, np. Ogród Saski. Unikać należało ponadto nazwy „wał”, a używać „okopy”. W przypadku niewielkich i wąskich uliczek (niem. Gasse) używać określenia „Zaułek”, np. Zaułek Bernardyński. Nie należało stosować nazw ulic warszawskich w rodzaju: Wspólna, Hoża, Niecała.

W zakończeniu jeszcze raz podkreślono, aby upamiętniając „mężów zasłużonych", starać się wskazywać zwłaszcza tych, którzy choćby po części zajmowali się zagadnieniami Słowiańszczyzny względnie działali (przebywali) na dawnych ziemiach polskich; w propozycjach autorów zaleceń pojawiły się w związku z tym nazwiska powszechnie raczej mało znane. W opracowaniu znalazła się adnotacja, że w sprawach wątpliwych należało się zwracać do Instytutu Zachodniego w Poznaniu (ul. Chełmońskiego 1) lub jego filii w Lesznie (ul. Bolesława Chrobrego 25/26). Zgodność pisma poświadczył kierownik Oddziału Ogólnego Wydziału Kultury i Sztuki Czesław Szłapka.

Trudno stwierdzić, w jakim stopniu i czy w ogóle dokument ten był znany w szerszym zakresie władzom administracyjnym innych terenów ziem przyłączonych do Polski po wojnie; część bowiem z zaleceń w nim zawartych była uwzględniana przy nadawaniu polskiego imiennictwa ulic na całym obszarze Ziem Zachodnich i Północnych, ale być może odbywało się to niejako intuicyjnie. Z drugiej strony, jak się okaże w dalszej części opracowania, badacze tej problematyki stwierdzają (zwłaszcza w przypadku Wrocławia), iż panował pewien „nieład”, gdyż nie było „żadnych wytycznych” w tym względzie, co by wskazywało na to, że owe „wytyczne” Instytutu Zachodniego jednak nie wszędzie dotarły.

\section{Działania nowej administracji}

Niektórzy autorzy zwracają uwagę, jak trudno było niekiedy dotrzeć do źródeł stanowiących podstawę do zmiany nazewnictwa ulic danej miejscowości po wojnie. Pisze o tym Andrzej Chludziński w swym dwuczęściowym artykule dotyczącym nazw ulic Białogardu ${ }^{24}$, w którym stwierdza, iż mimo intensywnych wysiłków, nie udało mu się odnaleźć niektórych uchwał, w myśl których nadawano bądź zmieniano nazwy ulic białogardzkich; dotyczyło to zwłaszcza okresu 1945-1960 i później 1990-1995²5.

O tym, jak szybko podjęto działania urzędowe w sprawie przemianowania nazw ulic, może świadczyć pismo Starosty Powiatowego (M. Nowickiego) w Bytowie, który już 22 czerwca 1945 r. przesłał do Zarządu Miejskiego gotowy spis przemianowanych ulic miasta Bytowa „do wiadomości i stosowania w urzędowaniu” ${ }^{26}$. Polecił jednocześnie sporządzenie dokładnego spisu ulic $\mathrm{w}$ mieście i porównanie z załączonym 
wykazem, a także poinformowanie o przypadkach, kiedy dana ulica nie figuruje w wykazie ${ }^{27}$. Załączony wykaz obejmował 54 nazwy ulic w języku niemieckim oraz w brzmieniu polskim.

Wynika z niego, iż w większości nazwy ulic zostały przemianowane poprzez tłumaczenie, np. Blumenstrasse - ul. Kwiatowa, Friedhofstrasse - ul. Cmentarna, Bahnhofstrasse - ul. Dworcowa, Grünstrasse - ul. Zielona, Kanalstrasse - ul. Kanałowa, etc. W przypadku nazw odosobowych zmieniono nazwę również na odosobową, np. Johann Groethe Strasse - zmieniono na ul. Jana Kochanowskiego, Konrad von Jungingen Strasse - została ul. Grunwaldzką; nazwę upamiętniającą zakon krzyżacki: Deutschritter Strasse - zamieniono na ul. Husarską; część nazw wywodzących się od miast pozostawiono, np. Danzigerstrasse - została ul. Gdańską, Lauenburgerstrasse - ul. Lęborską, Thornstrasse - ul. Toruńską.

Z opracowania na temat historii miasta i gminy Żarów (pow. świdnicki, woj. dolnośląskie) wynika, że administracja polska natychmiast po rozpoczęciu swej działalności na tym terenie przystąpiła do jego „odniemczania”. W pierwszej kolejności dotyczyło to zmiany nazw miejscowości, a także ulic i placów, szyldów i napisów, jak również likwidowania wszelkich symboli związanych z państwowością niemiecką. Chodziło o jak najszybsze usunięcie „śladów panowania niemieckiego na polskich ziemiach"28. Zmiany nazw ulic były przeprowadzane w bardzo szybkim tempie; w Żarowie już na drugim posiedzeniu Rady Gminnej 27 lipca 1945 r. dokonano korekty i zatwierdzono nazwy ulic; podjęto też decyzję co do przebiegu uroczystości nadania im polskich nazw ${ }^{29}$. Jeśli chodzi o nazwy ulic i placów Żarowa, to prawie wszystkie zostały zmienione już w okresie lipiec-sierpień 1945 r. ${ }^{30}$ Uroczystość związana z nadaniem ulicom Żarowa nowych nazw odbyła się 29 lipca $1945 \mathrm{r}$. i miała na tyle istotne znaczenie, że donosiły o tym obszernie „Wiadomości Świdnickie” (2 sierpnia 1945 r.). Opisany przebieg wydarzeń oddawał wiernie klimat i realia polityczne panujące wówczas nie tylko na Ziemiach Zachodnich i Północnych, ale też w całej, „uzależnionej od Moskwy Rzeczypospolitej”31.

Z komunikatu władz Lęborka w sprawie zmiany nazw ulic z dnia 20 maja 1946 r. (a więc po roku funkcjonowania już nazw polskich na terenie Lęborka) można wywnioskować, jakie gremia (organy) współuczestniczyły w ostatecznym nadawaniu polskiego imiennictwa ulicom miasta oraz jaki był tryb ich zatwierdzania.

27 Burmistrz Bytowa [A. Kazimierczak] przesłał 14 I 1946 r. do Starostwa Powiatowego oraz do Powiatowej Komendy MO pismo z nazwami 4 ulic i dzielnic, które nie posiadały dotąd nazw, zob. Zarząd Miejski m. Bytów, opr. Adm. 2/25/46.

28 Cyt. za: ibidem.

29 Zarząd Gminy Żarów powstał w czerwcu 1945 r., a pierwsze posiedzenie Rady odbyło się 25 VI 1945 r.; wójtem Żarowa został Stanisław Chojnacki, zob. Polskie nazwy ulic Żarowa majq już 70 lat, za: http://www. izba.centrum.zarow.pl/artykuly/454-polskie-nazwy-ulic-zarowa-maja-juz-70-lat (dostęp: 26 IX 2015 r.).

30 W myśl rozporządzenia pełnomocnika Piaskowskiego z 12 VI 1945 r., dotyczącego zmiany nazw miejscowości: „brzmienie historyczne nazw polskich” przywrócono w 12 (na 19) miejscowościach obecnej gminy Żarów; późną jesienią nadano nazwy polskie pozostałym 7 miejscowościom gminy. Zob. ibidem.

31 Ibidem 
Zarząd Miejski miasta Lębork wydał mianowicie Ogłoszenie, podpisane przez ówczesnego burmistrza, Henryka Nosowskiego, w którym podał do wiadomości „ostateczne brzmienie nazw ulic m. Lęborka" [wytłuszczenie zgodne z oryginałem pisma], ustalone na posiedzeniu Miejskiej Rady Narodowej z dnia 12 kwietnia 1946 r., zgodnie z opinią Towarzystwa Kultury i Oświaty, uwzględniające również poprawki komisji M.R.N. ${ }^{32}$. Poniżej dołączono wykaz nazw (obejmujący 130 nazw ulic i placów) w postaci tabeli, ujętych w porządku alfabetycznym według nazw niemieckich. Tabela obejmowała ponadto "dotychczasową nazwę polską" oraz „nazwę uchwaloną”.

$\mathrm{Z}$ analizy zawartych $\mathrm{w}$ wykazie nazw wynika, iż ponad połowa używanych dotąd nazw polskich została zmieniona. $\mathrm{W}$ większości zmiana ta wynikała $\mathrm{z}$ nadania im nowych patronów, np. ul. Lwowską (Am Lemberg) zmieniono na ul. Wita Stwosza, ul. Torpedy (Am Lokomotiv) na ul. Żeromskiego, ul. Przyklasztorną (Am Kloster) na ul. Grotgera ${ }^{33}$, ul. Kwiatową (Blumenstr.) na ul. Sienkiewicza, ul. Ochronną (Am Schützen) na ul. Paderewskiego, ul. Szeroką (Breitestr.) na ul. Łokietka, ul. Środkową (Mittelstr.) na ul. Bolesława Prusa, ul. Parkową (Wilhelmstr.) na ul. Wyczółkowskiego, ul. Bydgoską (Brombergstr.) na ul. Słowackiego, ul. Wileńską (Büchnerstr.) na ul. Okrzei, etc. Niekiedy zmieniono też nazwy o brzmieniu neutralnym na nazwy o wydźwięku symbolicznym, np. ul. Wiśniową (Wendeweg) zmieniono na ul. Pionierów, ul. Leśną (Kukuksweg) na ul. Komuny Paryskiej, ul. Graniczną (Am Grenzen Graben) na ul. Harcerzy, ul. Władysława IV (Lessingstr.) zmieniono (co dziwne) na ul. Witosa.

Utrzymano nazwy, zmienione już w 1945 r., którym patronowali słynni kompozytorzy, malarze, pisarze, np. ul. Moniuszki (dawniej Mozartstr.), ul. Szopena [w spolszczonej wersji nazwiska kompozytora] (Bachstr.), ul. Wyspiańskiego (Beethovenstr.), ul. Konopnickiej (Drewkestr.), ul. Orzeszkowej (Kopelstr.). Zachowano też nazwę ulicy: Św. Wojciecha (Albertstr.), a także: ul. Bieruta (Auguststr.), ul. Stalina (Bismarckstr.), ul. Kaszubską (Zinzellzerstr.), ul. Gdańską (Danzigerstr.), etc.

\section{Likwidowanie śladów niemczyzny w nazwach ulic większych aglomeracji} W każdym z miast wprowadzanie polskiego imiennictwa ulic odbywało się w różnym tempie i w nieco inny sposób, choć widać też wiele podobieństw. Na ogół dość szybko udawało się władzom lokalnym uporać z tym problemem. Trudniejsza sytuacja była, co oczywiste, na terenie dużych miast ze względu na skalę problemu, czyli dużą liczbę ulic, które musiały jak najszybciej ulec spolszczeniu; w mniejszych miejscowościach było to znacznie prostsze, jak wynika z dalszej części opracowania. Na wybranych przykładach zostanie zobrazowane, w jaki sposób poradzono sobie z kwestią nadania wszystkim ulicom w dużych i mniejszych miastach na Ziemiach Zachodnich i Północnych polskiego imiennictwa, a także jakimi kryteriami się kierowano oraz jaki towarzyszył temu klimat. O tym, jak trudny był proces zmiany imiennictwa

\footnotetext{
32 Zob. Komunikat władz Lęborka 1946 dot. zmiany nazw ulic z niemieckich na polskie; udostępnił Zbigniew Wołocznik, http://lebork.trim.pl/lauenburg-in-pommern/komunikat-wladz-leborka-1946-dotzmiany-nazw-ulic-z-niemieckich-na-polskie/ (dostęp: 26 IX 2015 r.).

33 W wykazie pisownia nazwiska Grottgera występuje przez jedno „t”; trudno stwierdzić, czy była to jedynie zwykła pomyłka w sporządzeniu wykazu.
} 
ulic w okresie powojennym, świadczy fakt, iż z uwagi na wymóg chwili musiało się to odbywać w szybkim tempie, to zaś powodowało, że nie zawsze nazwy zostały dobrze przemyślane, toteż zdarzało się, że dochodziło później do powtórnych zmian.

\section{Wrocław - trudne początki}

W badaniach nad "odniemczaniem” i polonizacją dawnego Breslau i późniejszego Wrocławia Magdalena Helmich, Jakub Kujawiński, Margret Kutschke i Juliane Toman skupili uwagę na dwojakiego rodzaju przekazie: z jednej strony był to przekaz ustny (oral history), a z drugiej świadectwa zapisane w przestrzeni miejskiej. Narodowy charakter przestrzeni miasta daje się odczytać - ich zdaniem - na dwóch poziomach: na poziomie języka komunikacji związanego z obszarem życia codziennego, czego wyrazem są nazwy ulic, szyldy i napisy publiczne, oraz na poziomie treści symbolicznych, odnoszących się świadomie do historii narodu i państwa, wyrażonych w języku bądź artefaktach, przy czym niejednokrotnie obie te sfery nakładają się na siebie ${ }^{34}$.

Pokazując nieznane oblicze Wrocławia, Tamara Barriga zauważyła, iż przed II wojną światową niektóre z ulic dawnego Breslau obok nazw niemieckich miały swoje odpowiedniki polskie ${ }^{35}$. Na ogół nosiły one imiona bohaterów historycznych oraz nazwy wydarzeń narodowych; większość z nich nie miała jednak politycznych znaczeń (np. na Sępolnie ulicom patronowały różne gatunki ptaków, a na Biskupinie - postaci z bajek). Sytuacja ta zmieniła się po zakończeniu wojny.

Język nazw ulic musi być zrozumiały dla mieszkańców danego miasta; było więc rzeczą oczywistą, że po wojnie niemieckie nazwy ulic przestały być funkcjonalne i musiały ulec zmianie. Szczególnie trudne zadanie miały w tym względzie do wykonania nowe władze w tak dużej aglomeracji, jaką jest Wrocław: ok. 1500 ulic i placów w mieście musiało wówczas zmienić swe imiennictwo. Nadawanie miastu polskiego oblicza dokonywało się we Wrocławiu stopniowo, acz systematycznie; władze zajęły się urzędowo usuwaniem wszelkich śladów niemieckości; likwidowano pomniki, napisy niemieckie, nazwy ulic, placów i dzielnic. Początkowo jednak panował pod tym względem „wszechwładny nieład” ${ }^{36}$. Pierwszy krok w kierunku bardziej uporządkowanych działań uczynił ówczesny prezydent miasta, Bolesław Drobner, wydając rozporządzenie, na mocy którego przedwojenny Plac Zamkowy (Schlossplatz) stał się Placem Wolności. Zmianę tę zalecono przeprowadzić możliwie jak najszybciej, gdyż 26 maja $1945 \mathrm{r}$. miała się na nim odbyć polska parada zwycięstwa ${ }^{37}$.

34 M. Helmich, J. Kujawinski, M. Kutschke, J. Toman, „Odniemczanie” i polonizacja czyli z niemieckiego Breslau powstaje polski Wrocław, [w:] Polski Wrocław jako metropolia europejska - Pamięć i polityka historyczna z punktu widzenia oral history, red. Ph. Ther, T. Królik, L. Henke, https://homepage.univie.ac.at/ philipp.ther/breslau/html/odniemczanie.html (dostęp: 19 X 2005 r.).

35 T. Barriga, Mickiewicz zamiast Hitlera, Chrobry za Bismarcka. Wrocławskie ulice i ich nazwy, http:// www.tvn24.pl/wroclaw,44/mickiewicz-zamiast-hitlera-chrobry-za-bismarcka-wroclawskie-ulice-i-ichnazwy,329729.html (dostęp: 1 VI 2013 r.).

36 M. Jankowska, op. cit., s. 90.

37 Ibidem. 
W okresie 1945-1946 brakowało we Wrocławiu właściwego organu, wyposażonego w odpowiednie kompetencje do nadawania nazw ulicom, a na szczeblu samorządowym brakowało przepisów regulujących postępowanie w sytuacjach kryzysowych, jak zwróciła uwagę Marta Jankowska ${ }^{38}$. W rezultacie nastąpiło „samoistne wyposażenie się" Zarządu Miejskiego we Wrocławiu w kompetencje administracyjno-prawne do przeprowadzenia zmian nazewnictwa miejskiego. Zmian tych dokonywał Zarząd Miejski Wrocławia i zatwierdzał je w formie uchwał; następnie były one podawane do publicznej wiadomości w postaci okólników ${ }^{39}$. Dopiero w późniejszym terminie Zarząd Miejski powołał w ramach Wydziału Ogólnego specjalną Komisję do Zmian Nazw Ulic ${ }^{40}$, która rozpoczęła prace latem $1945 \mathrm{r}^{41} \mathrm{~W}$ ramach wydziału (a później Resortu Technicznego) istniał Oddział Zabudowy i Pomiarów, którego pracownicy zajmowali się m.in. opracowaniem planów ogólnych, wytyczaniem ulic i placów, a także ich nazewnictwem ${ }^{42}$.

Pierwszą wzmiankę o uchwale dotyczącej zmiany nazw ulic można spotkać w Protokole nr 7 z posiedzenia Zarządu Miejskiego (27 lipca 1945 r.). Przemianowania dotyczyły pięciu najważniejszych ulic w mieście, były to: Adolf-Hitler-Strasse, którą zmieniono na ul. Adama Mickiewicza, Bismarckstrasse - na ul. Bolesława Chrobrego, Matthiasstr, której nadano nazwę ul. Generalissimusa Stalina, Schweidnitzer - i Neue Schweidnitzerstrasse nazwano ul. Świdnicką oraz Tiergartenstrasse, którą przemianowano na ul. Marii Curie-Skłodowskiej ${ }^{43}$. Najpierw przystąpiono do zmiany nazw ulic w centrum miasta; a na przedmieściach nazwy nadano jedynie głównym ulicom ${ }^{44}$.

W grudniu 1945 r. naczelnikiem Wydziału Kultury, Sztuki i Szkolnictwa w Zarządzie Miejskim (ZM) we Wrocławiu został (przeniesiony z Wydziału Prawnego) Andrzej Jochelson, prawnik, pisarz i tłumacz, przybyły do Wrocławia z Krakowa; wkrótce dołączył też do składu Komisji do Zmiany Nazw Ulic ${ }^{45}$. Był on jedną z osób,

38 Podobnie uważa K. Kędziora, która stwierdziła, iż początkowo nie było żadnych wytycznych dotyczących zasad, jakimi należało się kierować w dokonywaniu zmian nazewnictwa ulic; opracowano je dopiero dwa lata później, co zostało ujęte w zaleceniach Prezydenta RP; wtedy jednak większość ulic i placów miała już swe nowe nazwy. Nie jest to zgodne z prawda, gdyż istniały zalecenia oparte na przesłankach naukowych w tym względzie, opracowane przez Instytut Zachodni (zob. omówienie powyżej). Z tego wynika natomiast, iż być może nie było wówczas należytego przepływu informacji między organami administracji państwowej w poszczególnych okregach Ziem Zachodnich i Północnych badź też kontaktów z instytutami naukowymi, które mogły być (i były) pomocne, jak chociażby wspomniany wyżej Instytut Zachodni.

39 Szerzej na temat funkcji i mocy prawnej okólników zob. M. Jankowska, op. cit., s. 94-95.

40 W literaturze można też spotkać nazwę Komisja Nazewnictwa, zob. H. Okólska, Władze miejskie Wrocławia w latach 1945-1948, Wrocław 2005, s. 35.

41 M. Jankowska, op. cit., s. 91.

42 H. Okólska, op. cit., s. 35.

43 Ibidem, s. 36.

44 Ibidem.

45 W skład Komisji wchodzili ponadto: Stefan Podgórski (wiceprezydent Wrocławia) jako przewodniczący, a także: Antoni Knot (dyrektor Biblioteki Uniwersyteckiej), Józef Rybicki (naczelnik Wydziału Budowlanego), Mieczysław Kofta (naczelnik Wydziału Informacji i Propagandy, ojciec Jonasza Kofty). 
którym zależało na tym, by uporać się ze sprawą zmiany nazewnictwa ulic w mieście w sposób kompleksowy. Postawił to sobie niejako za punkt honoru i - jak wspominał - znacznie przyspieszył tempo ich przemianowywania. Twierdził, że o ile przedtem w trakcie 3-4 konferencji zmieniono nazwy ok. 120 ulic, o tyle później, podczas jednego posiedzenia zmieniono ich aż $150^{46}$, a na kolejnym posiedzeniu - dalszych 120. Niestety, jak ubolewał, następne trzy posiedzenia nie doszły do skutku ${ }^{47}$.

Jego idea, by natychmiast usunąć wszystkie nazwy niemieckie i zastąpić je odpowiednikami polskimi, budziła jednak spore opory we władzach miasta. Dowodzono, że tak gwałtowna zmiana stanie się źródłem nieładu i spowoduje duże trudności dla funkcjonowania ludności w mieście. Postanowiono zatem, że przemianowanie ulic Wrocławia będzie następowało stopniowo. Jochelson był dumny ze swego wkładu w przyspieszenie prac Komisji; do końca stycznia 1946 r. już połowa nazw ulic w mieście miała swe polskie odpowiedniki. Po każdym posiedzeniu komisji Jochelson sporządzał trzy rodzaje list: A) zawierała ulice z nazwami niemieckimi i zmienionymi polskimi, B) obejmowała ulice z nowymi nazwami polskimi i dawnymi niemieckimi oraz $\mathrm{C}$ ) niezmienione jeszcze nazwy niemieckie. Jochelsona nazywano „tytanem pracy"; z przekazów ustnych wynikało, że w ciągu jednej nocy potrafił przygotować spis ok. 1000 polskich nazw ulic. Potwierdzają to jego zapiski: „Ogółem nasza Komisja opracowała 1250 nazw, z czego większa część była mojego autorstwa, ponieważ osobiście dokonywałem przekładów, choć wiele ulic otrzymało nowe, polskie nazwy"48.

Po utworzeniu Komisji do Zmiany Nazw Ulic został zmodyfikowany nieco tryb ich zmieniania, tzn. nadal organem uchwalającym zmiany był Zarząd Miasta, jednak projekty zmian musiały być zgłaszane najpierw do Komisji. Propozycje nazw mogły być skądinąd zgłaszane również przez inne podmioty, np. przez organizacje społeczne bądź grupy obywateli. W maju 1946 r. rozpoczął działalność nowo utworzony organ administracyjny: Miejska Rada Narodowa (MRN), która stała się sukcesorem prawnym Zarządu Miejskiego. Do jej kompetencji należały odtąd sprawy związane z nazewnictwem; procedura zmiany nazw ulic do 1950 r. pozostała taka sama. W okresie od 16 lipca 1945 r. do 15 maja 1946 r. ukazało się w sumie 10 okólników (oraz 1 uchwała) zawierających przemianowane już nazwy; w sumie było to ok. 1090 nazw ulic, 47 nazw dzielnic oraz 15 nazw mostów ${ }^{49}$.

Marta Jankowska wyróżniła osiem schematów, według których dokonywano przemianowania nazw; określiła je „tendencjami”: 1) tendencja historyczna (przywrócenie nazw sprzed germanizacji), 2) tłumaczenia (dosłowny przekład nazwy ulicy), 3) tendencja stalinizacji (np. Matthiasstrasse na ul. Generalissimusa J. Stalina), 4) tendencja odosobowa (w ramach tego samego rodzaju zawodowego, przemianowanie poprzez

47 M. Jankowska, op. cit. s. 91.

48 A. Jochelson, Kronika Semipałatyńsk - Wrocław, Wrocław 1997, cyt. za: M. Jankowska, op. cit., s. 91.

49 Jest to przybliżona liczba, wynikająca ze zsumowania przemianowanych nazw ulic ujętych w poszczególnych okólnikach; aczkolwiek M. Jankowska uważa, iż są to dane jedynie orientacyjne, gdyż w okólnikach zdarzały się błędy, powtórzenia, nieścisłości, etc. zob. M. Jankowska, op. cit., s. 95-96. 
znalezienie polskiego odpowiednika (np. Agnes Sormastrasse na Heleny Modrzejewskiej), 5) tendencja niezobowiązująca (osoba za osobę), 6) zmiana nazwy polskiej na nową nazwę polską, 7) zmiana niemieckich nazwisk na nazwę odprzymiotnikową i odwrotnie (np. Gustav Freytagstrasse na Dyrekcyjną lub Rossmarktstrasse na Karola Szajnochy), 8) zmiana niemieckich nazw odprzymiotnikowych na polskie nazwy odprzymiotnikowe (np. Groschengasse na Menniczą)50. Można powiedzieć, że w dużej mierze przyjęty przez autorkę schemat dokonywania przemian w nazewnictwie ulic Wrocławia można odnieść (z pewnymi modyfikacjami) również do innych (zwłaszcza większych) miast na Ziemiach Zachodnich i Północnych, choć odbywało się to w różnych kombinacjach.

Za doborem patronów kryły się określone treści symboliczne wyrażone poprzez nazwy, na co zwrócili uwagę Magdalena Helmich, Jakub Kujawiński, Margret Kutschke i Juliane Toman, prowadząc we Wrocławiu badania nad jego historią, w tym także zmianami nazewnictwa ulic po $1945 \mathrm{r} .{ }^{51}$ Nie wszędzie zmiana nazw mogła się dokonywać poprzez tłumaczenie; tak było głównie w przypadku ulic skupionych wokół Starego Miasta, gdzie nazwy miały jeszcze częściowo rodowód średniowieczny (np. Nikolaistrasse pozostawiono jako ul. Św. Mikołaja). W zmianie nazewnictwa ulic ważne było przede wszystkim pozbawienie ich związków z niemiecką historią miasta, toteż np. Blücherplatz zmieniono na pl. Solny, Tauentzienplatz zmieniono na pl. Kościuszki, co wyraźnie podkreśliło jego polski charakter. Tendencja ta była widoczna zwłaszcza wówczas, gdy w nazwach odwoływano się do konfliktów polsko-niemieckich, np. Kaiser-Wilhelmstrasse zamieniono na ul. Powstańców Śląskich, a Kaiserbrücke zmieniono na most Grunwaldzki ${ }^{52}$. Okazję do umacniania polskiego oblicza Wrocławia stwarzało wytyczanie nowych ulic i placów.

\section{Gdańsk - „oswajanie miasta”}

Podobnie jak na całym terenie Ziem Zachodnich i Północnych, tak również w Gdańsku nowe władze stanęły wiosną 1945 r. przed ogromnym wyzwaniem, jakim było nadanie miastu polskiego charakteru. Nowym mieszkańcom trzeba było zbudować nową tożsamość. Historyk Jan Daniluk, badacz i znawca dziejów Gdańska w XIX i XX w. oraz historii ziem polskich wcielonych do Rzeszy, a także Prus Wschodnich, określił te pierwsze działania „oswajaniem miasta” ${ }^{33}$. Obok wielu innych zadań administracyjnych należało do tego stworzenie nowego (polskiego) systemu nazewnictwa. Przemianowanie wszystkich nazw ulic, placów, skwerów nie było łatwe z uwagi na ich liczbę; według szacunków pod koniec „niemieckiej” historii Wolnego Miasta Gdańska było ich ok. 1100; większość z nich musiała zmienić po wojnie, co zrozumiałe, swych patronów.

51 Zob. M. Helmich, J. Kujawinski, M. Kutschke, J. Toman, „Odniemczanie”....

52 Ibidem

53 J. Daniluk, Oswajanie miasta. O zmianach nazw ulic w powojennym Gdańsku, http://historia.trojmiasto.pl/Oswajanie-miasta-O-zmianach-nazw-ulic-w-powojennym-Gdansku-n101787.html (dostęp: $19 \mathrm{~V}$ 2016 r.). 
Pierwsze działania w kierunku spolszczania nazw niemieckich podjęto już 1 maja 1945 r. Spektakularne było przemianowanie trzech najważniejszych arterii komunikacyjnych w mieście: dotychczasowej Adolf-Hitler-Strasse na al. Grunwaldzką, Hindenburgallee - na al. Marszałka Rokossowskiego (obecnie al. Zwycięstwa) oraz Heumarkt - na pl. 1 Maja (obecnie Targ Sienny). Oficjalne nadanie polskich nazw przez władze miasta miało miejsce podczas uroczystości związanych z obchodami Święta Pracy, na które złożyły się: wiec, pochód oraz akademia 1-majowa $^{54}$. Nazwy polskie zostały starannie dobrane i miały jasne przesłanie; pierwsza odwoływała się do zwycięskiej bitwy polskiego oręża nad zakonem krzyżackim pod Grunwaldem (co w obliczu współczesnej klęski Niemiec miało wydźwięk szczególny); druga była uhonorowaniem dowódcy II Frontu Białoruskiego, który „wyzwolił” m.in. Gdańsk; trzecia oznaczała zwycięstwo „ludu pracy” (co miało wymiar symboliczny dla nowego ustroju).

Nie były to pierwsze polskie nazwy, jakie pojawiły się w Gdańsku, gdyż, jak podaje Daniluk, na życzenie sowieckiego Komendanta Wojennego Oliwy działający w Oliwie organ polskiej władzy już 22 kwietnia 1945 r. podjął decyzję o przemianowaniu ulicy Am Schlossgarten na ul. Armii Radzieckiej oraz ulicy Am Markt - na pl. Armii Polskiej (obecnie noszą one nazwy: Opata Jacka Rybińskiego oraz Stary Rynek Oliwski). Istnieją ponoć przesłanki, by przypuszczać, że władze miasta nie bardzo chciały zaakceptować nazwy nadane nie z własnej inicjatywy. W pierwszym (roboczym) wykazie ulic Gdańska (z początku sierpnia 1945 r.) widnieje propozycja, by ulicę Am Schlossgarten przemianować na ul. Kazimierza Jagiellończyka, natomiast Am Markt - na pl. Wyzwolenia Gdańska. W rezultacie jednak, prawdopodobnie pod wpływem „nacisków” sowieckich, w październiku 1945 r. Miejska Rada Narodowa podjęła wiążącą decyzję (w postaci uchwały), by formalnie podtrzymać jako obowiązujące nazwy, które funkcjonowały już od kwietnia. Należy dodać, że obie wspomniane nazwy zniknęły z przestrzeni miasta na fali tzw. dekomunizacji na początku lat 90. XX w. Natomiast proponowana wcześniej nazwa placu Wyzwolenia Gdańska nie została nigdzie uwzględniona ${ }^{55}$.

Proces przygotowania polskiego nazewnictwa ulic w Gdańsku przebiegał etapami. Pierwsze jego zręby w postaci wykazu nazw ulic przygotowano już w sierpniu 1945 r.; część z ustalonych wstępnie nazw pojawiła się jednak już wcześniej na tabliczkach umieszczanych przy najważniejszych drogach, by umożliwić komunikację w mieście; do końca lipca w Gdańsku było ich już ok. 200; potrzeby były jednak znacznie większe. Nadal na wielu tablicach widniały dawne, niemieckie nazwy ulic; były jednak przekreślone czerwoną kreską bądź częściowo zasłonięte. Nazywano to ponoć „listkiem figowym polskości” (Daniluk). Było rzeczą oczywistą, że proces nadawania polskich nazw ulic będzie wymagał czasu ze względu na skalę problemów. Nic więc dziwnego, że prawie do końca 1945 r. w prasie (w artykułach czy ogłoszeniach) używano na przemian nazw polskich i niemieckich. 
Intensywne prace nad ustalaniem polskich nazw ulic toczyły się przede wszystkim jesienią 1945 r., a zwłaszcza w ciągu 1946 r. W kolejnych miesiącach starano się systematycznie porządkować nazewnictwo miejskie Gdańska; wtedy też dokonano podziału miasta na dzielnice; ich nazwy zostały ostatecznie ustalone jednak dopiero w 1949 r. (wówczas przeprowadzono ostatnie korekty, ujednolicono zapisy, połączono kilka nazw ciągów komunikacyjnych, nadając im jedną nową). Zdarzało się, że część ulic, których nazwy zostały już przetłumaczone w latach 1945-1946, później zniknęła z przestrzeni miasta, gdyż nie wybudowano przy nich domów bądź innych obiektów, a z drugiej strony na nowych osiedlach powojennego Gdańska zaczęły powstawać nowe ulice. Nadawano też nazwy miejscom, które nie posiadały nazwy przed rokiem 1945, np. pl. gen. Władysława Sikorskiego przed dworcem głównym PKP w Gdańsku otrzymał swą nazwę dopiero w 1946 r. (później w latach 1953-1991 przemianowany został na pl. Maksyma Gorkiego) ${ }^{56}$.

Dopiero jednak w drugiej połowie 1947 r. (a może nawet w 1948 r., gdyż - jak pisze Daniluk - źródła nie dają na ten temat jednoznacznej informacji) przyjęto formalnie opracowany spis nowych nazw ulic w mieście. Systematyczna wymiana tablic i zastępowanie nazw niemieckich polskimi odbywała się ostatecznie w latach 1948-1949. W Gdańsku, tak jak i w innych miastach, gros nazw upamiętniało postacie oraz wydarzenia związane z nowym ustrojem komunistycznym w Polsce i co za tym idzie z „przyjaźnią” polsko-radziecką (czy też „polsko-radzieckim braterstwem broni"). Obok nich funkcjonowały nazwy sławiące zasłużone postaci z życia politycznego i naukowego, np. ul. Kołłątaja (Prittwitzer Weg), Staszica (Coselweg), Kopernika (Schopenhauerweg), Skłodowskiej-Curie (Delbrückallee), Lelewela (Labesweg), a także polityków i działaczy (socjalistycznych) z II RP (przez pewien okres), np. al. Gabriela Narutowicza (Gossler Alle), al. Wincentego Witosa (Obbergenweg), Mieczysława Niedziałkowskiego, Norberta Barlickiego, Romana Dmowskiego (Schlageter Straße/Bahnhofstraße).

Dla zobrazowania pewnych trendów (schematów) w zmianie nazewnictwa ulic w okresie powojennym warto przyjrzeć się bliżej, jak wyglądały poszczególne przemianowania w Gdańsku i jego dzielnicach. Przykłady te pozwalają bowiem dostrzec pewne prawidłowości i cechy charakterystyczne tego procesu w każdej z dzielnic Gdańska; niekiedy zaś wskazują na brak konsekwencji i swoistą dowolność w nadawaniu gdańskim ulicom imiennictwa polskiego.

Należy zwrócić uwagę, że w różnych dzielnicach Gdańska upamiętnione zostały przede wszystkim ważne wydarzenia związane z polskim ruchem robotniczym, a także przypominające bohaterów, bohaterskie czyny bądź też działania zbrojne, np. powstała ul. Powstańców Warszawskich (Heinrich-Scholtz-Weg), pl. Obrońców Poczty Polskiej (Heveliusplatz), ul. Gdyńskich Kosynierów (Rennerstiftsgasse); w Gdańsku-Wrzeszczu utworzono: al. Wojska Polskiego (Friedrich-Allee), pl. gen. Maczka (Friedrichs-Platz), al. Zwycięstwa (Große Allee/Hindenburg Alle), ul. Legionów (Heeresanger), ul. Boh. Getta Warszawskiego (Rickertweg), ul. Marynarki 
Polskiej (Paul-Beneke-Weg), a także ul. Matki Polki (Seyfertweg/Mirchauer Promenade) oraz ul. Gomółki (Schlüterweg); w Gdańsku-Brzeźnie (Brösen) znalazła się ul. Młodzieży Polskiej (Jungstraße) i ul. Walecznych (Victoriastraße). W dzielnicy Gdańska-Nowy Port nadano nazwy: pl. Demokratów (Wilhelmplatz), pl. Wolności (Wilhelmstraße). Były też ulice upamiętniające działaczy niepodległościowych, np. Romualda Traugutta (Am Heiligenbrunn/St. Michaellsweg), Ludwika Waryńskiego (Brunshöferweg); niektóre nazwy ulic upamiętniały sojuszników z Wielkiej Brytanii czy USA (np. al. Prezydenta Roosevelta, ul. de Gaulle'a (Ulmenweg), al. Sprzymierzonych, ul. Obrońców Londynu, etc.). Nota bene również w innych miastach występowały tego typu nazwy, np. w Lęborku istniała ul. Aliantów (Präsident Sohn). Wraz z umacnianiem się pozycji nowej władzy zaczęto niektóre z nazw zastępować nowymi; i tak powstały: ul. gen. Karola Świerczewskiego, ul. Batalionów Chłopskich, ul. Jedności Robotniczej i in. Pod koniec lat 40. XX w. pojawiły się też nazwy odnoszące się do miejscowej historii ${ }^{57}$.

Na terenie dzielnicy Gdańsk-Wrzeszcz (Langfuhr) oraz Gdańsk-Nowy Port (Neufahrwasser) w nazwach ulic upamiętniono królów polskich, np. Zygmunta Augusta (Arthur-Conrad-Straße), Bolesława Chrobrego (Brösenerweg), Jana III Sobieskiego (Königstaler Weg), Stefana Batorego (Steffensweg), Władysława IV (Bergstraße). Przede wszystkim jednak patronami ulic w tych dzielnicach zostali pisarze i poeci; były to np. Mickiewicza (Bärenweg), Konopnickiej (Baumbachallee), Tuwima (Lindenstraße), Fredry (Emil-Berenz-Strasse), Słowackiego (Hochstrieß), Sienkiewicza (Friedenssteg), Kraszewskiego (Herbert-Norkus-Straße), Krasickiego (Neufahrwasserweg), Reja (Leegstrieß), Prusa (Scharmer Straße), Kochanowskiego (Posadowskiweg), Orzeszkowej (Opitzstraße), Klonowicza (Marienweg); w nazwach ulic upamiętniono też licznych kompozytorów polskich, np. ul. Chopina (Winterfeldweg), Szymanowskiego (Hohenfriedbergweg), Żeleńskiego (Kesseldorfweg), Nowowiejskiego (Seydlitzweg), Karłowicza (Torgauer Weg), oraz malarzy, np. ul. Matejki (Johannistal), Wyspiańskiego (Neuschottland), etc. Zdarzały się też ulice: Zbyszka z Bogdańca (Westerzelle), Jana z Kolna (Schichaugasse) czy Trubadurów (Jachmannstraße) ${ }^{58}$.

W dzielnicach Gdańsk-Orunia (Ohra) oraz Gdańsk-Oliwa (Oliva) ulice wywodzące się od nazwisk osób związanych z ideologią nazistowską otrzymały nazwy pochodzące od nazw miejscowości bądź nazwy neutralne, np. Theodor-von der Pfordten-Straße przemianowano na ul. Zamojską, Horst-Wessel-Straße na ul. Nowiny, Litzmannstraße na ul. Grabową, Andreas-Bauriedl-Straße - na Raduńską; z kolei ulice, którym patronowali niemieccy reformatorzy, myśliciele, badacze, pisarze, a także bohaterowie narodowi Prus i Niemiec, nazwano częściowo imieniem polskich twórców, a częściowo od nazw miejscowości, np. Goethestraße przemianowano na ul. Tetmajera, Lessingstraße na Grottgera, Walter-Flex-Straße na ul. Sowińskiego,

57 Szerzej o późniejszych zmianach w nazewnictwie ulic Gdańska do 1953 r. oraz o obecnych odpowiednikach nazw zmienionych po wojnie zob. ibidem.

58 Wybór przykładów na podstawie wykazu ulic w: Dawne nazwy ulic gdańskich, za: http://www.danzig-online.pl/nazwy/uliced.html (dostęp: 2 I 2017 r.). 
Wichertstraße na ul. Lenartowicza, Lützowstraße na Poznańską, Humboldtstraße na Słowiańską, natomiast Hardenbergstraße na ul. Husa, Scharnhornstraße na ul. Stefana Miraua (lekarza i społecznika w Wolnym Mieście Gdańsku).

W Gdańsku-Suchaninie (Zigankenberg) nazwy ulic, którym patronowali kompozytorzy niemieccy, zostały zachowane, np. Beethovenweg pozostało ul. Beethovena, Franz-Schubert-Weg - ul. Schuberta, Mozartweg - ul. Mozarta, Richard-Wagner-Weg - ul. Wagnera (było to dość nietypowe, gdyż na ogół nazwisko Wagnera zamieniano na innego kompozytora polskiego), Robert-Schumann-Weg - ul. Schumanna. W Sopocie (Zoppot) Adolf-Hitler-Straße/Danziger Straße otrzymała nazwę ul. Niepodległości, Horst-Wessel-Straße/Königstraße nazwano ul. Armii Krajowej, a Schefflerstraße - ul. Hołdu Pruskiego, Hindenburgallee zmieniono na ul. Prusa, Bismarckstraße na ul. Pułaskiego, Moltkestraße - na ul. Fiszera, Wilhelmstraße została ul. Haffnera, Büllowallee ul. Mickiewicza, a Haffnerstraße zmieniono na ul. Sobieskiego, Georg-Holz-Weg na ul. Traugutta, Heidenbergstraße na ul. Kochanowskiego, Beethovenstraße na ul. Książąt Pomorskich, Lessingstraße została ul. Głowackiego, Richard-Wagner-Straße zmieniono na ul. Moniuszki, a Wagnerstraße - otrzymała nazwę ul. Helskiej, Schillerstraße została ul. Polną, Victoriastraße - ul. Królowej Jadwigi, Seestraße przemianowano na ul. Boh. Monte Cassino ${ }^{59}$.

We wszystkich tych zmianach trudno dopatrzyć się jakiejś sztywnej zasady, według której zmieniano nazwy niemieckie na polskie; jedno jest wszakże zauważalne, mianowicie, iż najczęściej zmiany polegały na wprowadzaniu patronów polskich w miejsce dotychczasowych niemieckich; zdarzało się też, że nazwy odosobowe zmieniano na nazwy mające upamiętniać ważne wydarzenia z historii Polski, fakty historyczne, bądź też wprowadzano nazwy neutralne.

Obok nazw odosobowych powstało też wiele nazw poprzez tłumaczenie (dosłowne bądź zbliżone), np. Am Bärenwinkel przemianowano na Niedźwiednik, Nordstraße zostało ul. Północną, Bischofsberg - ul. Biskupią, Breitgasse - stała się ul. Szeroką, Fischmarkt - przemianowano na Targ Rybny, a Fleischergasse - na ul. Rzeźnicką, Fuchswall - zostało Lisią Groblą, Heilige-Geist-Gasse - ul. św. Ducha, Langgasse została ul. Długą, Kohlengasse - ul. Węglarską, Postgasse - ul. Pocztową, Schlossgasse - ul. Zamkową, Sperlinggasse - ul. Wróblą, Stiftsgasse - ul. Fundacyjną, Theatergasse - ul. Teatralna, Birkenallee - została ul. Brzozową, Grünes Dreieck został - Zielonym Trójkątem, a Maiglöckenweg - ul. Konwalii etc. Przytoczone przykłady pozwalają stwierdzić, że w większości były to jednak dosłowne odpowiedniki nazw niemieckich.

Przybliżenie procesu „oswajania” miasta poprzez liczne przykłady zmiany nazw poszczególnych ulic z niemieckich na polskie w różnych dzielnicach Gdańska pozwala lepiej dostrzec specyfikę podejmowanych w tej mierze decyzji w każdej z dzielnic miasta. Pokazuje też naocznie, jak różny charakter miały te przemianowania. 


\section{Zielona Góra - braki w dokumentacji}

Sytuację panującą w nazewnictwie ulic w Zielonej Górze w pierwszych dniach i miesiącach po zakończeniu II wojny światowej opisał szczegółowo znawca tej problematyki, Wiesław Myszkiewicz, oddając wiernie klimat, jaki towarzyszył tworzeniu się polskiej państwowości na tym terenie. Należy przypuszczać, że podobnie było też w innych miastach, kiedy powstawały dopiero zalążki polskiej administracji i spraw pilnych i bardziej pilnych było co niemiara. Myszkiewicz, zwrócił uwagę, iż z zachowanych dokumentów wynika, że nadawanie nazw polskich ulicom nie należało chyba w tym „polskim już mieście” do spraw najpilniejszych, gdyż nie ma w nich $\mathrm{w}$ zasadzie wzmianek na temat podejmowanych w tym kierunku działań; można znaleźć co najwyżej informacje o zaistniałych już faktach ${ }^{60}$.

Nie chcąc używać nazw niemieckich, mieszkańcy stosowali często bezpośrednie tłumaczenie polskie, posługiwali się kalkami językowymi. Nowi osadnicy odczuwali zarazem potrzebę wprowadzania nazw nie tylko o polskim brzmieniu, ale też „osadzonych w kręgu polskiej tradycji kulturowej”61. Według badań Myszkiewicza nowe nazwy otrzymało w 1945 r. już 167 ulic Zielonej Góry: z tego 37\% stanowiły tłumaczenia dawnych nazw niemieckich; nowe nazwy otrzymały ulice, którym nadano nazwy personalne. Nie zachowano żadnej nazwy, która byłaby związana z osobą Niemca (niezależnie od tego, kim był i czego dotyczyła jego działalność). Zlikwidowano wszystkie nazwy upamiętniające nie tylko twórców niemieckiej polityki (co oczywiste), ale nawet osoby związane z kulturą niemiecką, a także nazwiska osób wywodzących się z Zielonej Góry oraz osobistości zasłużonych dla rozwoju miasta. Z dalszej części niniejszego opracowaniu wynika, iż podobne praktyki były też stosowane w przypadku innych miast ziem zachodniej i północnej Polski.

W Zielonej Górze 48 ulic, jak podaje Myszkiewicz, otrzymało nazwy od postaci historycznych i legendarnych, od bohaterów powstań narodowych oraz twórców kultury. W nowych nazwach nie odwoływano się jednak do okresu dwudziestolecia międzywojennego ani do okresu I i II wojny światowej; nie nadano też ani jednej nazwy związanej z postaciami ruchu robotniczego; polityczny wymiar miały nazwy ulic: 1 Maja, 3 Maja oraz Plac Bohaterów. Wśród nowych nazw znalazły się też takie, które podkreślały słowiańskość tych terenów (np. Plac Słowiański, ul. Łużycka, ul. Braniborska). W mieście nie zabrakło nazw ulic odnoszących się do militarnej przeszłości (ul. Artyleryjska, ul. Ułańska). Pozostałe nazwy miały różnorodny charakter; część z nich odnosiła się do wyglądu ulicy, jej położenia bądź kierunku. Proces nadawania nowych nazw ulic trwał jeszcze do roku 1946, kiedy uzupełniano nazwy ulic peryferyjnych. Zakończenie etapu powojennych zmian i kształtowania nazewnictwa ulic w Zielonej Górze (wraz z różnymi przemianowaniami) nastąpiło w 1947 r. ${ }^{62}$ 
Sposoby adaptacji niemieckich nazw ulic Zielonej Góry do polskiego systemu językowego z językoznawczego punktu widzenia oraz określenie typów nowych nazw ulic w powojennej historii miasta omówiła szczegółowo Iwona Żuraszek-Ryś w artykule Jak powstały nowe nazwy ulic w powojennej Zielonej Górze? ${ }^{63} \mathrm{Z}$ jej badań wynika, iż trudno w zasadzie stwierdzić, czym kierowały się osoby odpowiedzialne za polonizację dotychczasowych niemieckich urbonimów: „Wiele nazw ulic motywowanych apelatywami zastąpiono nazwami pochodzącymi od antroponimów, a w przypadku nazw pochodzących od nazw osobowych - wyrazami pospolitymi"64. Jej zdaniem uzasadniona była polonizacja onimów pochodzących od nazwisk niemieckich polityków czy dowódców, ale trudno dociec, dlaczego większość z tych nazw zastąpiono apelatywami, a nie antroponimami. Równie niezrozumiałe jest, w jej przekonaniu, dlaczego zmieniono niektóre nazwy kierunkowe, skoro w pierwszym okresie powojennym nie doszło bynajmniej do przebudowy istniejącej sieci komunikacyjnej. Tego rodzaju zmiany trudno uznać, jej zdaniem, za uzasadnione; mogło to wynikać jedynie z dość pospiesznie przeprowadzonej i „nieprzemyślanej” polonizacji. Nie wiadomo nawet, czy powołano w tym celu jakiś specjalny zespół składający się z osób kompetentnych; być może nie utworzono takiego gremium, czego dowodem może być fakt, że jedynym świadectwem dotyczącym polonizacji nazw ulic w Zielonej Górze jest pięciostronicowy dokument w postaci maszynopisu (bez daty i podpisu), zawierający spis nazw niemieckich i odpowiadające im nazwy polskie. Jest to „jeden z ważniejszych dokumentów w powojennej historii miasta”, dowodzi I. Juraszek-Ryśs ${ }^{5}$. Z jej badań wynika, że nowe nazwy ulic w powojennej Zielonej Górze świadczą o tym, że były różne sposoby adaptacji niemieckich urbonimów do polskiego systemu językowego, a osoby odpowiedzialne za przeprowadzenie polonizacji nazw ulic musiały się zmierzyć z problemami natury językowej, a także pozajęzykowej, co powodowało, że niektóre z przyjętych wówczas rozwiązań mogą budzić obecnie zastrzeżenia.

\section{POLONIZACJA NAZW ULIC W MNIEJSZYCH MIASTACH}

\section{1. Świdnica - „nieporozumienia” w tłumaczeniach}

Tworzenie zrębów polskiej administracji w Świdnicy rozpoczęło się 17 maja 1945 r.; przybyła wówczas pierwsza 30-osobowa grupa „operacyjna” mająca stworzyć jej podwaliny. Oficjalny wykaz nazw ulic miasta został opublikowany w „Wiadomościach Świdnickich" (nr 1/1945) 29 lipca 1945 r. Wynika z niego, że do końca lipca tego roku polskie nazwy otrzymało 119 ulic i placów; kilkanaście (niewielkich) uliczek

63 Zob. I. Juraszek-Ryś, Jak powstały nowe nazwy ulic w powojennej Zielonej Górze?, „Poznańskie Studia Polonistyczne", Seria Językoznawcza, t. 19 (39) (2012), z. 1, s. 159-171.

64 Ibidem, s. 170. 
otrzymało nazwy w terminie późniejszym ${ }^{66}$. Według Wiesława J. Raszkiewicza wykaz ten zawierał jednak sporo błędów wynikających z tego, że pierwszy numer gazety był drukowany jeszcze na niemieckich czcionkach, w dość prowizorycznych warunkach i dużym pośpiechu. Obecnie nadal obowiązuje $95 \mathrm{z}$ pierwotnie nadanych nazw, aczkolwiek niektóre z nich miały niekiedy wieloletnią „polityczną” przerwę.

Raszkiewicz przedstawił w swym artykule interesującą historię zmian nazw ulic świdnickich w okresie powojennym wraz z interpretacją sposobu ich spolszczania, a także historię niektórych nazw ulic sprzed 1945 r. Opublikował ponadto Zestawienie nazw ulic niemieckich obejmujące nazwy 288 ulic i placów Świdnicy ( $w$ formie tabeli) wraz $\mathrm{z}$ ich zmianami w ostatnich 80 latach; są one przedstawione w porządku alfabetycznym według schematu: 1) nazwa z 1944 r.; 2) wcześniejsze nazwy niemieckie (w odniesieniu do niektórych z nich); 3) nazwy polskie z $2012 \mathrm{r}$. oraz 4) wcześniejsze nazwy polskie ${ }^{67}$.

Część z nowo utworzonych nazw (zwłaszcza tradycyjnych, sprzed 1933 r.) powstała, o czym można się przekonać, analizując wspomniany wykaz ulic, w wyniku tłumaczenia, np. Rathausgasse została ul. Ratuszową (1945-1948, później ul. Wewnętrzną), Schlachthofstrasse - ul. Rzeźnicką (później - ul. Rzeźniczą), Petersstrasse zamieniono na ul. Piotrkowską (1945-1948, później została ul. Bohaterów Getta), Grünstrasse - zmieniono na ul. Zieloną (później na ul. Romualda Traugutta), Gartenstrasse została ul. Ogrodową (później ul. Joachima Lelewela), Untere Bolkostrasse została ul. Księcia Bolko (1945) (obecnie jest ul. Saperów), Wasserstrasse pozostała ul. Wodną (1945-1948, następnie ul. Zofii Jaroszewicz, 1948-1992, po czym znów powróciła nazwa: ul. Wodna). Z tego wynika, że drugi etap zmian w nazewnictwie polskich już nazw ulic w Świdnicy miał miejsce w $1948 \mathrm{r}$.

Śledząc historię zmian nazw ulic świdnickich, Raszkiewicz wskazał na pewne „nieporozumienia”, jakie powstawały niekiedy przy tłumaczeniach niektórych nazw niemieckich, np. Eichendorfstrasse została zmieniona na ul. Dębową; jego zdaniem wynikało to stąd, iż z nazwiska niemieckiego poety epoki romantyzmu Eichendorffa przetłumaczono jedynie pierwszy człon nazwiska, czyli „Eiche” - „dąb”. Podobnie było z innymi nazwami ulic, np. Kupferschmiedestrasse, której nazwa wywodziła się od nazwy zawodu kotlarz, przetłumaczono również tylko pierwszy jej człon, czyli „Kupfer” „miedź”, i stąd wzięła się nazwa ul. Miedziana. Jeszcze bardziej frapująca wydaje się zmiana nazwy Holteistrasse, której nazwa wywodziła się od nazwiska pisarza związanego z Wrocławiem: Karla von Holteia (1798-1880); jej nazwę zmieniono na ul. Włóczęgów. Według Raszkiewicza są dwie możliwości interpretacji nadania takiej właśnie nazwy: albo jej autorom to nieznane nazwisko skojarzyło się z polskim słowem „hultaj”, albo też ktoś znał jednak twórczość owego dramatopisarza, gdyż jedna z jego sztuk nosi tytuł Włóczędzy, co sprawiło, że nazwano ją ul. Włóczęgów; w 1975 r. nazwę ulicy

66 W.J. Raszkiewicz, Nazwy ulic $w$ Świdnicy, http://www.mojemiasto.swidnica.pl/?p=1151 (dostęp: $23 \mathrm{~V}$ 2012 r.).

67 W.J. Raszkiewicz, Zestawienie nazw ulic niemieckich, http://www.mojemiasto.swidnica.pl/?p=1165 (dostęp: 23 V 2012 r.). 
przemianowano ponownie na: ul. Klonową ${ }^{68}$. Przykładów tego rodzaju dziwnych przemianowań można by przytoczyć znacznie więcej również z terenu innych miast.

Interesujący jest też przypadek opisany przez Raszkiewicza uhonorowania postaci marszałka Michała Roli-Żymierskiego, który stał się patronem pierwotnie dwóch ulic tworzących jeden ciąg komunikacyjny: Burgstrasse (obecnie ul. Grodzka) i Friedrichstrasse (obecnie ul. Komunardów). W związku z tym, że prawdopodobnie wynikały z tego tytułu pewne utrudnienia administracyjne, to uchwałą Miejskiej Rady Narodowej (12 listopada 1946 r.) górną część ulicy „odebrano” marszałkowi i oddano pod patronat Ignacemu Daszyńskiemu. Nota bene marszałek Rola-Żymierski mógł odwiedzić „swoją” część ulicy, gdy przybył do Świdnicy na wiec przedwyborczy w styczniu $1947 \mathrm{r}$. Kolejne zmiany w nazwach obu ulic nastąpiły w latach 50. XX w., kiedy obu patronom ulice „odebrano” (po śmierci Stalina zaczęła obowiązywać zasada, iż nie wolno nadawać ulicom nazw wywodzących się od osób żyjących); ul. Daszyńskiego przemianowano wówczas na ul. Komunardów, a Żymierskiego na ul. Karola Świerczewskiego (w 1993 r. nazwę zmieniono na ul. Grodzką).

Równie ciekawe są przypadki zmiany nazw innych ulic, zwłaszcza w kontekście argumentacji, jaką się posługiwano, np. ulicy Kroischstrasse, która została w 1945 r. nazwana pierwotnie imieniem Karola Marksa, odebrano w 1949 r. patronat, uznając, iż ze względu na znajdujący się przy nim obiekt (więzienie) nazwa ta nie pasuje do tak „szacownego" patrona; ówcześni decydenci „przydzielili” więc Marksowi inną ulicę (dawną ul. Miedzianą), natomiast dotychczasową ul. Marksa przemianowano na ul. Trybunalską (później w latach 80. XX w. część ulicy zmieniono na ul. Nauczycielską ${ }^{69}$. Warto jeszcze wskazać na charakterystyczną zmianę nazwy ulicy Strasse der SA na ul. Oświęcimską (1945-1956); później zmienioną ją na ul. Ofiar Oświęcimskich. Różne etapy przemianowań przeszedł też Martin-Luther-Platz zamieniony w 1945 r. na pl. Lenina, a następnie pl. Świętej Małgorzaty (nawiązując do nazwy placu sprzed 1933 r. Margaretenplatz).

Pozostawiono natomiast nazwy ulic wywodzących się od miast, np. Breslauerstrasse - została nazwana ul. Wrocławską (1945-1950), którą w latach 50. XX w. przemianowano na ul. Stalingradzką (1950-1956), następnie funkcjonowała znów jako ul. Wrocławska (1956-1975), a ostatecznie została ul. Szarych Szeregów; z kolei Waldenburger Str. - została ul. Wałbrzyską (1945-1949, którą zmieniono później na ul. Hanki Sawickiej (1949-1992), po czym ponownie wróciła nazwa ul. Wałbrzyskiej.

Na tych przykładach widać wyraźnie, jak dalece ideologia wkraczała w obszar imiennictwa miejskiego.

\section{Bytom - zasłużeni dla Śląska patroni}

W krótkim szkicu zatytułowanym Jak nadawano bytomskim ulicom i placom polskie nazwy Piotr Obrączka stwierdził, iż w 1945 r. „nie zerwano całkowicie z tradycją 
nazewniczą bytomskich ulic - wiele nazw uległo po prostu spolszczeniu"70. Przywołał następnie wspomnienie prof. Władysława Studenckiego (opublikowane w jego Wieczorach bytomskich w 1967 r.), które znakomicie oddaje atmosferę tamtego czasu, a także wskazuje na przesłanki, jakimi kierowały się osoby zajmujące się nadawaniem polskich nazw w miejsce dotychczasowych niemieckich. Warto zatem zacytować słowa Studenckiego, które ilustrują wyraźnie tok rozumowania i idee, jakie przyświecały twórcom nowego, polskiego imiennictwa ulic tuż po wojnie. Uwagi te można odnieść skądinąd nie tylko Bytomia, ale prawdopodobnie także do wielu innych miast i miasteczek śląskich. Oto, jak wyglądało w praktyce projektowanie nowego nazewnictwa polskiego:

Z panem Włodzimierzem Markowskim [nauczycielem w Bytomiu] (...) zasiedliśmy wiosną 1945 r. przy lampie naftowej nad wielką mapą Bytomia, aby nadać ulicom brzmienie polskie. Włodzimierz, doświadczony w sprawach śląskich, wysuwał zasłużonych tej ziemi: Lompę, Miarkę, Webera, Wieczorka, Witczaka... Podawałem z kolei nazwiska bohaterów polskich umęczonych w obozach - pisarzy, wybitnych uczonych, artystów, działaczy. Biało-czerwoną flagą otoczyliśmy Bytom, w którym niedawno temu zwisały flagi hitlerowskie najeżone szponami swastyk ${ }^{71}$.

W nazwach ulic bytomskich upamiętniono zatem osoby zasłużone dla Śląska, takie jak ks. Norbert Bonczyk, Karol Miarka, Jan Ligoń, a także osoby, które straciły życie w obozach koncentracyjnych, np. pracownicy gimnazjum polskiego w Bytomiu: Stanisław Olejniczak (nauczyciel), ks. Franciszek Nawrot (katecheta), Antoni Józefczyk (administrator budynków gimnazjum). Podobnie jak w innych miastach obowiązkowo uhonorowano też władców polskich (Bolesława Chrobrego, Jana III Sobieskiego, Stefana Batorego, Królową Jadwigę); swoje miejsce w nazwach ulic znaleźli też kompozytorzy (Chopin, Moniuszko, Szymanowski), malarze (Matejko, Grottger, Juliusz Kossak, Chełmoński, Wyczółkowski), pisarze (Mickiewicz, Kraszewski, Sienkiewicz, Prus, Fredro, Kasprowicz, Reymont, Żeromski i in.). Ulica śląskiego rzeźbiarza (Teodora Kalidego) otrzymała nazwę malarza, rysownika i grafika okresu Młodej Polski, Teodora Axentowicza, a ulicę śląskiego pisarza Paula Kellera zmieniono na ul. Marii Konopnickiej; kompozytora F. Schuberta (Franz-Schubert-Str.) zastąpił Fryderyk Chopin; z kolei Park Goethego został Parkiem Mickiewicza.

Nie zerwano jednak całkowicie z dotychczasową tradycją nazewniczą, co znalazło odbicie $\mathrm{w}$ dosłownym tłumaczeniu nazw utworzonych przede wszystkim od miejscowości sąsiadujących z Bytomiem bądź w jego pobliżu, np. ul. Katowicka (Kattowitzerstr.), ul. Chorzowska (Königshütterstr.), ul. Gliwicka (Gleiwitzerstr.), Kędzierzyńska (Heydebreckstr.) czy też ul. Krakowska (Krakauerstr.). W tłumaczeniu zachowano też nazwę Rynku (Ring) oraz dwóch placów bytomskich: pl. Klasztorny (Klosterplatz)

70 P. Obrączka, Jak nadawano bytomskim ulicom i placom polskie nazwy, http://zyciebytomskie.pl/index. php/ZB/arch_art/jak-nadawano-bytomskim-ulicom-i-placom-polskie-nazwy (dostęp: 26 VIII 2013 r.). 
i Św. Barbary (Barbaraplatz), a także nazwy wielu ulic i uliczek wokół Rynku, np. ul. Różana (Rosengasse), Rycerska (Ritterstr.), Mariacka (Marienstr.), Murarska (Maurerstr.), Krawiecka (Schneiderstr.), jak również uliczek oddalonych od Rynku, np. ul. Sądowa (Gerichtsstr.), Dworcowa (Bahnhofstr.), Krzyżowa (Kreuzstr.), Browarniana (Braugasse), Akacjowa (Akazienweg), Klonowa (Ahornweg), Północna (Nordweg), Głęboka (Tiefgasse) etc. Jedyną niekonsekwencję dostrzegł Obrączka w przypadku ul. Grabowej (Birkenweg), która powinna zostać nazwana właściwie ul. Brzozową.

Na marginesie warto wspomnieć (mimo iż wykracza to poza ramy czasowe niniejszego artykułu), że współcześnie nieco inaczej spogląda się na swoje miasto i jego historię. Świadczą o tym słowa Obrączki, który zauważył, że na fali owego „odniemczania" nazw usunięto zarazem nazwiska zasłużonych dla Bytomia patronów ulic, np. nadburmistrza Georga Brüninga (ulicę jego imienia zmieniono na ul. Daszyńskiego, obecnie ul. Drzymały), kronikarza miasta Franza Gramera (zmieniono na ul. Tramwajarzy), kupca, radnego i filantropa Ignatza Hakuba (ul. Kraszewskiego), kompozytora urodzonego w Bytomiu Heinricha Schulza-Beuthena (ul. Sienkiewicza, obecnie ul. Kasperka) i in. Zdaniem Obrączki nadszedł czas, by niektóre z tych osób powróciły do przestrzeni publicznej miasta i ponownie stały się patronami bytomskich ulic. Za „ponury żart” uznał fakt, iż do tej pory nie doczekał się „własnej” ulicy jeden z najsławniejszych bytomian, ks. Grzegorz Gerwazy Gorczycki ${ }^{72}$. Piotr Obrączka podał też wiele innych interesujących przykładów przemianowań, jakie przechodziły kolejno niektóre nazwy ulic bytomskich zgodnie $\mathrm{z}$ tendencjami kształtowania nazewnictwa miejskiego według aktualnej koniunktury ideologiczno-politycznej (np. pl. Stalina, ul. Armii Ludowej, ul. PPR-u, ul. Bieruta, ul. Zawadzkiego, ul. Hanki Sawickiej, Pl. Czerwony i in.). Należy podkreślić, iż większość ulic i placów Bytomia nosi nadal nazwy, jakie nadano im w 1945 r.

\section{Legnica - wielokrotne zmiany nazw (patronów)}

Analiza materiałów dotyczących polonizacji nazewnictwa ulic w Legnicy pozwala zauważyć, iż w większości zostały one wprowadzone z dniem 16 stycznia 1946 r.; w niektórych przypadkach nazwy te były później zmieniane ponownie 22 lutego 1946 r. bądź półtora roku później 21 października $1947 \mathrm{r}^{73}$ Podobnie jak w wielu innych miastach, w nazwach ulic uwieczniono nazwiska królów polskich (np. Bolesława Chrobrego, Stefana Batorego), działaczy ruchu robotniczego (m.in. Stefana Okrzei, Mieczysława Niedziałkowskiego, Mariana Buczka), bohaterów i uczestników powstań narodowych (np. Karola Marcinkowskiego, gen. Mariana Langiewicza, Emilii Plater, Bartosza Głowackiego), działaczy społecznych i politycznych (m.in. Stefanii

73 W latach 50. i 60. XX w. do zmian w nazewnictwie ulic legnickich dochodziło raczej sporadycznie (zmieniano niekiedy ich patronów). Z analizy historii imiennictwa poszczególnych ulic w Legnicy wynika, że kolejna, większa fala ich przemianowań miała miejsce w nowych uwarunkowaniach społeczno-politycznych w Polsce na początku lat 90. XX w.; nowe brzmienie otrzymała większość z nich 5 VII 1991 r. Zob. portal historyczny „Liegnitz. pl. Miejsca: Ulice, place”, oprac. przez Macieja Szczęsnego Juniszewskiego, znawcy historii regionu i pasjonata imiennictwa miejskiego Legnicy, autora książki Nazwy ulic i placów Legnicy, Legnica 2000; zob. też http://www.liegnitz.pl/index.php?CAT/41 (dostęp: 10 XII 2017 r.). 
Sempołowskiej, Franciszka Ksawerego Lubeckiego-Druckiego, Henryka Jordana, Andrzeja Struga). Swoją ulicę otrzymał również prezydent [Franklin Delano] Roosevelt, jak również dowódca powstania w Getcie Warszawskim - Mordechaj Anielewicz. Ulicom legnickim patronowało też, podobnie jak gdzie indziej, grono pisarzy, poetów, muzyków, malarzy polskich (były ulice m.in. Adama Asnyka, Aleksandra Fredry, Jana Kasprowicza, Jana Kochanowskiego, Marii Konopnickiej, Zygmunta Krasińskiego, Jacka Malczewskiego, Adama Mickiewicza, Elizy Orzeszkowej, Ignacego Paderewskiego, Hugona Kołłątaja, Bolesława Prusa, Mikołaja Reja, Henryka Sienkiewicza etc.).

Okazuje się, że niekiedy, mimo ustaleń, dana nazwa występowała w różnej postaci. Tak było w przypadku ulicy prowadzącej do wioski Lubiatów, noszącej przed wojną nazwę Lobendauer Weg (Droga Lebiody), która 22 stycznia 1946 r. przyjęła nazwę ul. Lebodowska. W miesiąc później funkcjonowały aż cztery różne wersje jej nazwy: ul. Łebodowska, Libedorska, Lidoborska oraz Łobodowska. Ostatecznie 21 października 1947 r. nadano jej nazwę ul. Wincentego Witosa; później jeszcze dwukrotnie ulegała ona przemianowaniom: 26 stycznia $1952 \mathrm{r}$. została nazwana imieniem działacza ruchu robotniczego Władysława Hibnera i wreszcie 5 lipca 1991 r. mineraloga i geologa Ignacego Domeyki ${ }^{74}$.

Interesujące zmiany nazwy przechodziła obecna Aleja Marszałka Józefa Piłsudskiego, dawna Koischwitzer Straße. Pierwotnie była to droga poza obszarem miasta, która nosiła nazwę Todtenweg (Droga Zmarłych). Po jej włączeniu w granice miasta jej początkowy odcinek otrzymał nazwę Koischwitzer Straße (od nazwy wsi, do której prowadziła), natomiast część znajdująca się poza obrębem miasta nosiła nazwę Chausse nach Koischwitz. W latach 30. XIX w. przesunięto granice miasta w stronę Jawora ${ }^{75}$. W okresie powojennym 16 stycznia 1946 r., w ramach polonizacji nazw, ulica została nazwana ul. Kosowicką (od nazwy wsi Kosowice, do której prowadziła). Półtora roku później (21 października 1947 r.) nazwa ta ponownie uległa zmianie na ul. Koskowicką, ponieważ zmieniono nazwę wsi na Koskowice ${ }^{76}$. Warto wspomnieć, iż nazwę ulicy zmieniono później jeszcze dwukrotnie: 5 października 1966 r. na al. gen. Aleksandra Waszkiewicza ${ }^{77}$ oraz 5 lipca 1991 r. - na al. marsz. Józefa Piłsudskiego.

Ciekawie przedstawiały się też kolejne zmiany nazewnictwa dzisiejszej ul. Najświętszej Marii Panny, której nazwa na przestrzeni wieków była również kilkakrotnie zmieniana. Ponieważ łączyła ona dawną osadę przedlokacyjną w dolnej części miasta z Rynkiem górnego miasta i wiodła obok kościoła Marii Panny, nosiła w XV w. nazwę Beata Virgo (Błogosławionej Dziewicy). Zmiana wyznania wiary

77 Aleksander Waszkiewicz (1901-1945), Białorusin; od 1919 r. służył w Armii Czerwonej (otrzymał stopień pułkownika); od września 1944 r. skierowany do Wojska Polskiego; był dowódcą 5. Dywizji Piechoty: zginął w kwietniu 1945 r. podczas walk pod Budziszynem. Został pochowany w Warszawie; obecnie jego grób znajduje się na Cmentarzu Wojskowym na Powązkach. 
przez księcia i okolicznych mieszkańców na ewangelicką w połowie XVI w. spowodowała jednocześnie zmianę wezwania kościoła na: Unser Lieben Frau-Kirche, czego konsekwencją była z kolei zmiana nazwy ulicy na: Unser Lieben Frau Straße (Naszej Drogiej Pani); w XIX w. nazwę skrócono do: Frauenstraße ${ }^{78}$. Po wojnie, w ramach polonizacji nazw, ulicę nazwano początkowo ul. Panieńską (16 stycznia 1946 r.), a wkrótce potem przemianowano ją na ul. gen. Karola Świerczewskiego (nosiła tę nazwę w okresie: od 22 lutego 1946 do 21 października 1947 r.), po czym ponownie wrócono do nazwy ul. Panieńska, która obowiązywała z kolei do 29 czerwca 1955 r.; wówczas przemianowano ją na ul. Ethel i Juliusza Rosenbergów (na cześć amerykańskich komunistów straconych za szpiegostwo na rzecz Rosjan, m.in. za przekazanie materiałów dotyczących bomby atomowej). Kolejnej zmiany nazwy dokonano 5 lipca 1991 r., kiedy to nadano jej imię Najświętszej Marii Panny, nawiązując do jej pierwotnego brzmienia. Nie zdecydowano się wtedy na przywrócenie pierwszej nazwy powojennej: ul. Panieńska, obawiając się błędnej jej interpretacji ${ }^{79}$. Na tym przykładzie widać wyraźnie, że nie tylko względy ideologiczno-polityczne, ale nawet konfesyjne mogły niekiedy zaważyć na nazewnictwie ulic w różnych okresach historycznych.

\section{Będzin (Śląsk)}

Praktyki zmiany nazw w Będzinie w województwie śląskim przypominają metody przyjęte także $w$ innych miastach. Na podstawie analizy wykazu zmian nazewnictwa ulic będzińskich ${ }^{80}$ można się przekonać, że wiele ulic otrzymało przede wszystkim nazwy odosobowe, honorujące znane postaci (polityków, działaczy niepodległościowych, pisarzy, poetów, kompozytorów, malarzy), przy czym często otrzymywały je ulice, których nazwy w języku niemieckim były utworzone od obiektów na nich się znajdujących, np. Bahnhofstrasse przyjęła nazwę Tadeusza Kościuszki, Poststrasse - Janka Krasickiego (później Ignacego Krasickiego); Marktstrasse została przemianowana na ul. Feliksa Dzierżyńskiego (w okresie międzywojennym nosiła nazwę ul. Modrzejewskiej, obecnie wrócono ponownie do tej nazwy); Hospitalstrasse zmieniono na ul. Mariana Buczka (w okresie międzywojennym była to ul. Folwarczna/Ignacego Potockiego); Grenzstrasse - została nazwana ul. Juliana Marchlewskiego (współcześnie ul. Siemońska); Fabrikstrasse - otrzymała nazwę Henryka Sienkiewicza; Am Wasserwerk - ul. Stanisława Staszica; An den Garten ul. Juliana Tuwima; Steigerstrasse (Sztygarska) została nazwana ul. Żwirki i Wigury; Alte Hauptstrasse otrzymała nazwę Aleksandra Zawadzkiego /1975-1992/, dawniej była ul. Hugona Kołłątaja, współcześnie wrócono do tej nazwy); Johannstrasse pozostała ul. św. Jana (ale po 1958 r. przemianowano ją na ul. Stanisława Moniuszki);

78 Zob. Portal historyczny Liegnitz. pl., Najświętszej Marii Panny (Frauenstraße), http://www.liegnitz.pl/ index.php?OBJ/170 (dostęp: 12 XII 2017 r.).

79

Ibidem.

80 Zob. Zmiany nazewnictwa będzińskich ulic, za: https://pl.wikipedia.org/wiki/Zmiany_nazewnictwa_b\%C4\%99dzi\%C5\%84skich_ulic (dostęp: 7 VII 2016 r.). 
Hallenstrasse zmieniono na ul. Ludwika Waryńskiego (od 1992 r. nosi nazwę ul. Józefa Piłsudskiego, podobnie jak w okresie międzywojennym); Akazienweg nazwano ul. Jana Sobieskiego, obecnie to ul. Teatralna (od 1977 r.) etc. Trudno dociec, jaka była motywacja tego rodzaju przemianowań, skoro z powodzeniem można było pozostawić w gruncie rzeczy neutralne nazwy, takie jak ulice: Pocztowa, Rynkowa, Szpitalna, Graniczna, Fabryczna, Ogrodowa, Akacjowa etc.

Odrębną grupę stanowiły nazwy upamiętniające ważne wydarzenia historyczne, święta narodowe, bohaterów, np. Alterweg nazwano ul. Bohaterów Getta Warszawskiego (w okresie międzywojennym była to ul. Bożnicza/Żydowska); Kasernenstrasse - zmieniono na ul. 1 Maja; Hauptplatz - otrzymał nazwę pl. 3 Maja/pl. Bohaterów Stalingradu (1950), obecnie - pl. 3 Maja; Engerweg - nazwano ul. 15 Grudnia (przed wojną była to ul. Wąska); Vorwerkstrasse nazwano ul. 27 Stycznia (przed wojną ul. Folwarczna); Gartenstrasse przemianowano na ul. 22 Lipca (obecnie - ul. Sączewskiego, podobnie jak przed wojna); Talstrasse została zmieniona na ul. generalissimusa Stalina (27 lipca 1945 r.), obecnie - ul. Małobądzka (podobnie jak przed wojną); Marktstrasse przemianowano na ul. Feliksa Dzierżyńskiego (1958-1990), obecnie ul. Modrzejewskiej (dawna nazwa), a Brückenstrasse nazwano ul. Ormowców (1948-1992), w okresie międzywojennym - ul. Mostowa, a obecnie ul. Paryska; Bachstrasse została ul. Ludową (przed wojną była ul. Rzeczną).

Część nazw była zmieniana na zasadzie tłumaczenia, np. Eisenbahnstrasse - ul. Kolejowa, Kirchstrasse - ul. Kościelna, Kurzstrasse - ul. Krótka, Uferstrasse - ul. Nadbrzeżna, Steinstrasse - ul. Kamienna, Schulstrasse - ul. Szkolna, Dammweg - Grobla; we wszystkich tych przypadkach był to powrót do nazwy z okresu międzywojennego. Ale zdarzało się też, że np. Friedensweg (ul. Pokoju) zmieniono na ul. Krętą, chociaż przed wojną nazywała się ul. Zaciszną. Niektóre ulice/place otrzymały zupełnie nowe nazwy związane z utrwaleniem nowej władzy, np. pl. PKWN, pl. PCK, ul. Bolesława Bieruta (od 1990 r. nosi nazwę Władysława Andersa), ul. Stanisława Krzynówki (działacza komunistycznego), od 1992 r. - ul. Armii Krajowej ${ }^{81}$.

\section{Reszel (Warmia i Mazury)}

Polskie nazwy musiały otrzymać zwłaszcza te ulice, których nazwy uległy zmianie w okresie wojny i okupacji, a którym patronowały osoby „zasłużone” dla III Rzeszy. Z listy ulic reszelskich (2009 r.) uwzględniającej dawne nazwy niemieckie wynika, że na 54 ulice 27 nazw było związanych z upamiętnieniem ważnych postaci: królów, książąt, wodzów i dowódców (7), pisarzy, poetów, kompozytorów, malarzy (15) oraz osób związanych z Warmią i Mazurami (5). Pozostałe nazwy łączyły się z topografią terenu (16), a także z nazwami innych miejscowości (Kętrzyn, Racławice,

81 Szerzej na temat historii Będzina na przestrzeni dziejów oraz klasyfikacji semantycznej i strukturalnej nazw ulic Będzina zob. B. Ruszkiewicz, Nazwy ulic Będzina, „Językoznawstwo” XI, Zeszyty Naukowe Wyższej Szkoły Pedagogicznej im. Powstańców Śląskich w Opolu, 1988, s. 87-102. 
Płowce) etc. ${ }^{82}$ Oto kilka przykładów: Franz-Seldte-Strasse ${ }^{83}$ została zmieniona na Bolesława Chrobrego; Albert-Grunenberg-Strasse zmieniono na Plac Jana Ignacego Paderewskiego; Franz Stadtke-Strasse zamieniono na ul. Władysława Jagiełły; Georg-Matern-Strasse ${ }^{84}$ zamieniono na Stanisława Wyspiańskiego; Otto-Reinke-Strasse zmieniono na Józefa Zajączka ${ }^{85}$.

Nazwy odosobowe otrzymały też ulice, które uprzednio miały nazwy wywodzące się od miast: Rotdamweg przemianowano na Michała Kajki; Memeler-Strasse na Jana Henryka Dąbrowskiego; Thorner-Strasse otrzymała nazwę Waleriana Łukasińskiego ${ }^{86}$; Seeburger-Strasse przemianowano na ul. 1 Maja; podobnie było z nazwami wywodzącymi się od drzew: Kastanienallee otrzymała nazwę Mikołaja Kopernika, Ahornweg - Jana Kochanowskiego, Birkenweg - Cypriana Kamila Norwida; Lindenweg - Fryderyka Szopena (w spolszczonej pisowni); a także z nazwami wywodzącymi się od obiektów: Hospitalstrasse otrzymała nazwę Adama Mickiewicza, Schloßstrasse - Henryka Sienkiewicza, Torstrasse - Juliusza Słowackiego. Nazwy odosobowe otrzymały też ulice pochodzące od zawodów: Maurerstrasse została nazwana ul. Ignacego Józefa Kraszewskiego i inne: Schleusenstrasse przemianowano na Tadeusza Kościuszki; Neustrasse, Querstrasse przemianowano na Księcia Witolda; Neustadt na Władysława Reymonta.

\section{Maszewo (Zachodniopomorskie)}

W Maszewie, niewielkim miasteczku w środkowowschodniej części województwa zachodniopomorskiego, w pobliżu Nowogardu, Stargardu Szczecińskiego i Goleniowa, w większości ulicom nadano nazwy odosobowe: na 25 ulic - aż 11 z nich otrzymało nazwy honorujące polskich wieszczów, pisarzy, działaczy niepodległościowych (np. B. Głowackiego, S. Okrzei, ks. K. Świetlińskiego, K. Świerczewskiego, F. Chopina, H. Sienkiewicza, M. Buczka, A. Mickiewicza, T. Kościuszki, M. Konopnickiej). Pozostałym nadano nazwy upamiętniające ważne święta narodowe bądź pojęcia związane z utrwaleniem nowej władzy (ul. 22 Lipca, ul. Jedności Narodowej, ul. Wojska Polskiego, ul. 1 Maja, Plac Wolności, ul. 8 Marca). Kilka nazw było dosłownym tłumaczeniem nazwy niemieckiej (np. Birkenallee - stała się ul. Brzozową, Waldstraße - ul. Leśna,

82 Szerzej na temat nazewnictwa ulic w Reszlu zob. T. Rawa, O nazwach reszelskich ulic, http://www. reszel.pl/nazwach_reszelskich_ulic,23,1014.html (dostęp: 4 IX 2009 r.).

83 Franz Seldte (1882-1947), polityk, współtwórca paramilitarnej organizacji niemieckiej Stahlhelm, Bund der Frontsoldaten (Stalowy Hełm, Liga Żołnierzy Frontowych), nazistowski polityk, minister pracy w rządzie Hitlera.

84 Georg Matern (1870-1938), prałat, ur. w Pieniężnie, redaktor pisma „Ermländische Zeitung”, w parafii reszelskiej spędził 20 lat.

85 Józef Zajączek (1752-1826), książę, gen. piechoty; był gen. dywizji w armii napoleońskiej i Księstwa Warszawskiego; poseł na Sejm Czteroletni, namiestnik Królestwa Polskiego.

86 Walerian Łukasiński (1786-1868), działacz patriotyczny, mjr 4. pułku piechoty Księstwa Warszawskiego. 
Schulstraße - ul. Szkolną; zachowano też nazwy wywodzące się od miast: np. Neugarder Straße - ul. Nowogardzką, Stargarder Straße - ul. Stargardzką; natomiast Freiheider Chaussee ${ }^{87}$ zmieniono na ul. Lipową, a Scheller Weg na ul. Polną ${ }^{88}$.

Na podstawie przytoczonych wyżej przykładów można wysnuć wniosek, iż baczną uwagę zwracano przede wszystkim na to, aby w nowych nazwach upamiętnić znane postaci, zwłaszcza z dziedziny literatury i kultury.

\section{Jak przemianowano „obowiązkowe” nazwy niemieckie}

Adolf Hitler, jako naczelny wódz, musiał mieć w czasie wojny i okupacji, a nawet wcześniej, niemal wszędzie „swoją” ulicę; zazwyczaj jego imieniem nazywano główną arterię w mieście. Świadczy o tym chociażby fakt, iż mimo uregulowania trybu nadawania nazw ulic po przejęciu władzy przez NSDAP dochodziło również do samowolnych „weryfikacji” nazw dokonywanych przez nadgorliwych mieszkańców miast i miasteczek; tego rodzaju działania nie były jednak aprobowane i spotykały się niekiedy z „reprymendą” ze strony władzy zwierzchniej. Tak było na przykład w przypadku mieszkańców Księża Małego, którzy z własnej inicjatywy usunęli tabliczkę z nazwą Karl-Marx-Straße, zawieszając nową tabliczkę z nazwą Adolf-Hitler-Straße; gruppenführer SA Edmund Heines pouczył ich natychmiast, że „tego typu działań nie wolno podejmować”, gdyż „dla przywódcy NSDAP będzie przygotowana znacznie ważniejsza ulica w centrum miasta" ${ }^{89}$.

Poniżej przedstawiam kilka przykładów przemianowania takich „obowiązkowych" nazw ulic, występujących nie tylko w dużych miastach, ale również w niemal każdej mniejszej miejscowości.

Adolf-Hitler-Strasse (Adolf-Hitler-Allee, Adolf-Hitler-Platz): w Olsztynie Adolf-Hitler-Allee została zmieniona na al. Wojska Polskiego, a Adolf-Hitler-Platz zmieniono na pl. Wolności ${ }^{90}$; w Krośnie Odrzańskim: Adolf-Hitlerstrasse zmieniono na ul. Piastów; w Pile: Adolf-Hitler-Straße otrzymała nazwę ul. 11 Listopada; w Zielonej Górze: Adolf Hitler Platz zmieniono na pl. Marsz. Roli-Żymierskiego; we Wrocławiu: Adolf-Hitler-Strasse zmieniono na ul. Adama Mickiewicza; w Świdnicy Adolf-Hitler-Platz otrzymał nazwę pl. Grunwaldzki (do 1933 r. nosił nazwę Wilhelmsplatz); w Wałbrzychu zmieniono na Al. Wyzwolenia; w położonym nieopodal Wałbrzycha Białym Kamieniu (obecnie dzielnica Wałbrzycha) jego imieniem nazwano ul. Główną (Hauptstrasse), po wojnie została przemianowana na ul. Lenina, a ostatnio zmieniono jej nazwę na gen. Władysława Andersa; w Lęborku Adolf Hitler Strasse zmieniono na ul. I Armii Polskiej; w Łodzi Adolf-Hitler-Strasse zmieniono na ul. Piotrkowską (czyli wrócono do dawnej nazwy); w Reszlu Adolf-Hitler-Strasse (wcześniej Poststrasse) zmieniono na Kolejową, etc.

\footnotetext{
87 Freiheide - do 1945 r. nazwa wsi Godowo w pow. goleniowskim, niedaleko Maszewa.

88 Na podstawie zestawienia nazw ulic przed wojną i po jej zakończeniu, zob. Nazwy ulic miasta Massow do roku 1945 i Maszewa po roku 1945, https://www.maszewo.pl/informacje,gmina,ulice.html (dostęp: 2 I 2017 r.).
} 
Podobnie było w przypadku innych "obowiązkowych" nazw ulic, takich jak:

Hindenburg-Strasse (Hindenburgstrasse): w Świdnicy zmieniono ją na ul. Stefana Żeromskiego; w Bytowie nazwano ją ul. Mierosławskiego; w Reszlu Hindenburg-Strasse została zmieniona na ul. Ignacego Krasickiego; w Zielonej Górze Hindenburgplatz otrzymał nazwę Plac Bohaterów, a Hindenburgstr. zmieniono na ul. Bankową; w Olsztynie Hindenburgstr. zmieniono na ul. 1 Maja, a Hindenburghöhe na ul. Parkową; Hermann-Göring-Strasse: w Świdnicy Hermann-Göring-Str. zmieniono na ul. Tadeusza Kościuszki; w Olsztynie została przemianowana na ul. Limanowskiego/Sybiraków; w Krośnie Odrzańskim zmieniono ją na ul. Armii Krajowej; Rudolf-Hess-Strasse: w Łodzi Rudolf-Hess-Strasse zmieniono na al. Adama Mickiewicza (obecnie al. marsz. Józefa Piłsudskiego); Horst-Wessel-Strasse ${ }^{91}$ : w Świdnicy została zmieniona na ul. Józefa Stalina (1945-1956, później al. Niepodległości, a po 1966 r. - pl. 1000-lecia Państwa Polskiego); w Olsztynie Horst-Wessel-Str. zmieniono na ul. Przyjaciół; w Lęborku Horst-Wessel-Platz zmieniono na Pl. Kopernika; w Reszlu Horst-Wessel-Strasse (wcześniej Münchener-Strasse) zmieniono na ul. Warmińską; w Zielonej Górze Horst-Wessel-Platz zmieniono na Plac Słowiański; w Krośnie Odrzańskim Horst-Wessel-Ring zmieniono na Al. 1-go Maja; Moltke-Strasse (Moltkestrasse): w Świdnicy Moltkestr. - została ul. 1 Maja; w Olsztynie została ul. Kajki; w Lęborku zmieniono ją na ul. Dąbrowskiego; w Bytowie Moltkestrasse przemianowano na ul. Ratajczaka; w Zielonej Górze Moltkestr. otrzymała nazwę Kazimierza Wielkiego, w Krośnie Odrzańskim została ul. 17-tu Pionierów; Bismarckstrasse: w Olsztynie Bismarckstr. została ul. Mazurską; w Bytowie zmieniono ją na ul. Drzymały; we Wrocławiu - przemianowano ją na ul. Bolesława Chrobrego; w Krośnie Odrzańskim Bismarckstr. zmieniono na ul. Bolesława Chrobrego,

W Podgórzu (k. Wałbrzycha) główna ulica nazwana w 1939 r. Hindenburgstr. jest obecnie ul. Niepodległości; Hermann-Göring-Strasse po wojnie została ul. Lotników. Nazwy ulic sławiące pruskich wodzów: Blücher-Str. zmieniono na ul. Paderewskiego, Lutzow-Str. na ul. Szopena, a Moltke-Str. nazwano Psie Pole. Ulicę Heinrich-Heine Strasse, którą zniesiono w okresie III Rzeszy, gdyż jego twórczość uznano za „szkodliwą, dekadencką i niezgodną z duchem niemieckim”"92, zastąpiono Dietrich-Eckart-Straße, po wojnie zmieniono ją na ul. Rymanowską.

Z wszystkich tych przykładów wynika, iż nie było jakiejś sztywnej reguły, według której zmieniano nazwę ulicy lub placu upamiętniającego wodza III Rzeszy i innych jej przywódców; wygląda na to, że czyniono to w sposób dowolny; istotne było jedynie to, aby nowa nazwa była ważna z historycznego bądź kulturowego punktu widzenia.

91 Horst Wessel (1907-1930), nazista, SA-Sturmführer, autor tekstu do Horst-Wessel-Lied, pieśni, która stała się hymnem NSDAP.

92 Zob. Wałbrzych i okolice. Historia miasta na tle historii Dolnego Ślqska, rozdz. 8 (1933-1945), http:// blog.e-knapczyk.pl/walbrzych-i-okolice-historia-miasta-na-tle-historii-dolnego-slaska/rozdzial-viii-1933-1945/ (dostęp: 2 I 2017 r.). 


\section{8. Łódź - miasto o bogatej historii nazw}

Wprawdzie Łódź leży poza obszarem nakreślonym przez ramy niniejszego opracowania, ale warto poświęcić jej nieco więcej uwagi ze względu na specyfikę miasta, które wielokrotnie na przestrzeni dziejów przechodziło zmiany nazw ulic i placów. Szczególny był pod tym względem wiek XX, w którym doszło do wielu zawirowań politycznych. Sprzyjały temu zwłaszcza: I wojna światowa, okres międzywojenny (kiedy przywracano nazwy polskie i upamiętniano znane postaci), lata okupacji hitlerowskiej, kiedy wszystkie nazwy zostały zmienione na niemieckie pisane gotykiem. Kolejny punkt zwrotny w imiennictwie miejskim Łodzi stanowiło zakończenie II wojny światowej, co wymagało nadania wszystkim nazwom ulic polskiego brzmienia (częściowo przywrócono wówczas dawne nazwy sprzed 1939 r., a częściowo ustalono nowe, związane z utrwalaniem władzy ludowej) i wreszcie kolejny etap zmian w nazewnictwie ulic łódzkich nastąpił po przełomie ustrojowo-politycznym w Polsce w 1990 r.

Historię skomplikowanego nazewnictwa miejskiego w Łodzi można najlepiej prześledzić na wykazie nazw ulic i placów zamieszczonym na łódzkim portalu historycznym, który zawiera ich brzmienie w sześciu różnych okresach historycznych, w: 1913 r., 1925 r., 1933 r., w latach 1939-1945, do roku 1990 oraz nazwę współczesną³.

Tak jak w innych miastach, również w Łodzi w okresie 1939-1945 „swoją” ulicę miał naturalnie naczelny wódz Rzeszy: Adolf-Hitler-Strasse; główna ulica miasta została po 1945 r. ponownie ul. Piotrkowską (podobnie jak w okresach przed wojną); zmieniono też nazwy upamiętniające innych czołowych nazistów: Rudolf-Hess-Strasse po 1945 r. została przemianowana na al. Adama Mickiewicza (w 1925 i 1933 r. była ul. Głównąa4; Hermann-Göring-Strasse zmieniono na al. Tadeusza Kościuszki ${ }^{95}$ (dawniej: ul. Nowo Spacerowa); Horst-Wessel-Strasse zmieniono na ul. Nawrot ${ }^{96}$ (dawna nazwa); Moltkestrasse zmieniono na ul. Stefana Jaracza ${ }^{97}$ (dawniej: ul. Cegielniana, obecnie - ul. Stefana Jaracza).

W pierwszej kolejności musiały być zmienione też wszystkie inne nazwy upamiętniające dowódców i generałów pruskich, a także „zasłużonych” dla potęgi Niemiec i Rzeszy postaci, np. Scharnhorststrasse przywrócono dawną nazwę ul. 1 Maja;

93 Zmiany nazw i placów w Łodzi, Historie Łódzkie, Łódzki portal historyczny, http://www.historialodzi.obraz.com.pl/zmiany-nazw-ulic-i-placow-w-lodzi/ (dostęp: 13 I 2010 r.).

94 Istnieje pewna niejasność, gdyż w odniesieniu do niektórych nazw ulic, ważnych ze względu na osoby, jakie upamiętniały, podano w wykazie różne wersje nazw wcześniejszych, i tak np. Rudolf-Hess-Strasse widnieje dwukrotnie, raz podano, iż jej nazwa w 1933 r. brzmiała ul. Główna, a raz że była wówczas ul. Anny.

95 Podano też wersje, że Hermann-Göring-Strasse została zmieniona na ul. Zachodnią (we wszystkich okresach wcześniejszych i obecnie występuje również pod nazwą ul. Zachodnia; być może były dwie ulice upamiętniające Hermanna Göringa?).

96 Występują również dwie wersje: według drugiej wersji Horst-Wessel Strasse przemianowano na ul. Zamenhofa (i tak brzmiała też jej wcześniejsza nazwa, jedynie w 1913 r. nazywała się ul. Rozwadowską).

97 Według innej wersji Moltkestrasse przemianowano na ul. Śródmiejską (dawniej była ul. Nowo Cegielnianą, a obecnie - dr. płk. Stanisława Więckowskiego). 
Gneisenaustrasse nazwano ul. Lucjana Żeligowskiego (przed 1933 r. była ul. Leszno); Von-Ludendorff-Strasse została al. Politechniki (w 1925 r. była ul. Nowo-Pańską, w 1933 r. - ul. Żeromskiego); Hermann-von-Salza-Strasse przemianowano na Edwarda Abramowskiego (w 1925 r. była ul. Gubernatorską, w 1933 r. - ul. Edwarda Abramowskiego); Hindenburgplatz zmieniono na pl. Henryka Dąbrowskiego (wcześniej był pl. Dąbrowskiego); barwne koleje losu przechodziła General-Litzmann-Strasse zmieniona po 1945 r. na ul. Obrońców Stalingradu + Konstantynowską (przed 1933 r. była ul. 11 Listopada, w 1925 r. ul. Konstantynowską, obecnie: ul. Legionów + Konstantynowska); Wilhelm-Gustloff-Strasse przemianowano na ul. dr. Stefana Kopcińskiego (przed 1933 r. była ul. Zagajnikową); Hildebrand/Boelkestrasse zmieniono na ul. Edwarda Gibalskiego (przed 1933 r. - ul. Skłodowskiej); Schlageterstrasse została ul. Gabriela Narutowicza, przed 1933 r. - ul. Prezydenta Narutowicza). Zmieniono też wiele innych nazw, jak: Ulrich-von-Hütten-Strasse, Albert-Breyer-Strasse, Wilhelm-Heppner-Strasse, Deutsch-Orden-Strasse, a także nazwy, które upamiętniały znane postacie historyczne czy też ze świata nauki, np. Strasse Heinrichs-des-Löwen, Florian-Geyer-Strasse, Robert-Koch-Strasse ${ }^{98}$ etc.

Rzeczą charakterystyczną dla Łodzi było to, że niektóre ulice otrzymały w czasie okupacji nazwy zaczerpnięte z sagi o Nibelungach, uwiecznionej również w dziele Wagnera, np. Nibelungenstrasse, którą zamieniono na ul. 8-ego Marca (w 1925 r. ul. św. Emilii, w 1933 r. - ul. Emilii, obecnie ul. ks. bp. Wincentego Tymienieckiego); Walkürenstrasse po wojnie przywrócono wcześniejszą nazwę - ul. Brzeska; Wotanstrasse/Landsknechtstrasse zmieniono na ul. Sporną (dawna nazwa); Hertastrasse/Brunhildstr. została po wojnie ul. Stanisława Staszica (w 1925 r. była ul. Nowo-Marysińską, przed 1933 r. ul. Staszica); Walpurgisweg dano nazwę ul. Zmienna (wcześniej - Droga na Rogi). Były też nazwy upamiętniające ważnie dla Niemiec regiony: Prusy, kraje bałtyckie czy wyspę Helgoland: Ostpreussenstrasse po 1945 r. przywrócono wcześniejszą nazwę ul. Bednarska; Westpreussenstrasse przywrócono nazwę ul. Browarna; Baltenstrasse otrzymała dawną nazwę ul. Biegunowa; Helgolandstrasse została przemianowana na ul. Maurycego Bednarskiego (przedtem była ul. Słowackiego).

$\mathrm{Z}$ analizy nazw łódzkich ulic $\mathrm{w}$ różnych okresach historycznych $\mathrm{XX}$ w. figurujących w wykazie wynika, że po 1945 r. przywrócono w Łodzi w większości dawne nazwy, funkcjonujące przed $1933 \mathrm{r}$. W wielu wypadkach nazwy były zmieniane wielokrotnie, np. Nauländerstrasse/Neuländer (1939-1945) wcześniej: ul. Juliusza (19131939), po 1945 - ul. PKWN, współcześnie - ul. Dowborczyków; Königsbacher Strasse po 1945 - al. Armii Czerwonej (przedtem szosa Rokicińska, obecnie - al. marsz. Józefa Piłsudskiego).

Bardziej pogłębiona analiza pozwoliłaby z pewnością wyróżnić więcej kategorii zmiany nazewnictwa ulic w Łodzi; moim zamiarem było jedynie wskazanie na pewne zasadnicze tendencje, wykazujące duże podobieństwa do podstawowych przesłanek, jakimi się kierowano przy nadawaniu polskich nazw na obszarze Ziem Zachodnich 
i Północnych. Należy dodać, iż analizę materiału nazewniczego w przypadku Łodzi utrudniały w znacznym stopniu pewne nieścisłości występujące w wykazie; zdarzało się, że ta sama nazwa niemiecka pojawiała się dwukrotnie, „przypisana” do (dwóch) różnych nazw w języku polskim. Trudno dociec, czy były faktycznie dwie ulice mające tę samą nazwę niemiecką, którym później nadano różne nazwy polskie, czy też zaszła tu jakaś pomyłka. Również komentarze internautów zamieszczone pod wykazem świadczą o tym, że poprawność niektórych nazw (zwłaszcza w odniesieniu do nazw wcześniejszych, sprzed 1933 r.) może budzić wątpliwości.

\section{Zakończenie}

Nie sposób omówić wszystkich zmian w nazewnictwie ulic miast i miasteczek na Ziemiach Zachodnich i Północnych po 1945 r., ale już na podstawie przedstawionych przykładów jawi się obraz tego, jak wyglądał proces usuwania niemieckich nazw ulic i nadawania im nazw polskich w dwóch pierwszych latach po zakończeniu II wojny światowej.

Przede wszystkim widać wyraźnie, jak trudne to było zadanie głównie z uwagi na fakt, iż zmiana nazewnictwa ulic musiała być przeprowadzona możliwie jak najszybciej (ze względów administracyjnych i czysto praktycznych), co powodowało, że nie było czasu na dłuższe zastanawianie się, konsultacje czy też docieranie do źródeł, by stwierdzić, jaką nazwę dana ulica nosiła w przeszłości; brakowało też czasu na wypracowywanie reguł (kryteriów), według których należało przemianować nazwy ulic z niemieckich na polskie.

Jednocześnie brakowało doświadczenia i odpowiednio do tego zadania przygotowanej kadry. Zmianami nazw zajmowali się bowiem na ogół urzędnicy wchodzący w skład nowych struktur władzy administracyjnej (zarządów miejskich, zarządów gmin), nie dysponujący wystarczającym przygotowaniem merytorycznym i wiedzą historyczną do przeprowadzenia takiego zadania. Brak było też fachowców, którzy mogliby wesprzeć w tych działaniach organy administracyjne, a być może po prostu nie szukano z nimi kontaktu, aczkolwiek w niektórych przypadkach, jak wynika z opracowania, korzystano z zaleceń wskazanych przez naukowców (m.in. Instytutu Zachodniego w Poznaniu). Zdarzały się też przypadki, kiedy sprawą przemianowania nazw ulic zajmowały się osoby wysoce kompetentne (Wrocław, Bytom etc.).

Zachowało się niestety niewiele dokumentów (bądź też trudno do nich dotrzeć), które by pokazywały, jak faktycznie wyglądał tryb uchwalania nazw ulic: kto zgłaszał projekty nazw, czy były one dyskutowane i jakiego rodzaju poprawki były wprowadzane, a także czy budziły kontrowersje. Pewne światło na ten temat rzuca pismo Zarządu Miejskiego w Lęborku, z którego można wywnioskować, że gremium opiniodawczym było np. miejscowe Towarzystwo Kultury i Oświaty, a poprawki zostały wniesione przez Miejską Radę Narodową. Trudno jednak stwierdzić, czy podobnie działo się też $w$ innych ośrodkach. Odpowiedzi na te pytania wymagałyby jeszcze bardziej pogłębionych badań. Z pewnością inny wymiar (ze względu na liczbę) i przebieg miała zmiana imiennictwa ulic w mniejszych miejscowościach oraz w dużych aglomeracjach, zwłaszcza takich jak Wrocław, Gdańsk, Szczecin czy Olsztyn, gdzie projekty nazw były przygotowywane przez osoby kompetentne, a propozycje mogły 
zgłaszać także m.in. organizacje społeczne czy grupy obywateli, natomiast organem uchwalającym nazwy był Zarząd Miasta, a później Miejska Rada Narodowa.

Na podstawie szerokiego spektrum przykładów ilustrujących całą złożoność procesu przemian nazewnictwa ulic w okresie powojennym można wskazać na pewne generalne tendencje i kryteria, jakimi się kierowano w nadawaniu polskich nazw; przede wszystkim wprowadzano nazwy upamiętniające: 1) królów i władców polskich; 2) bohaterów narodowych i przywódców zwycięstw polskiego oręża; 3) zasłużone postaci z życia politycznego i naukowego; 4) polityków i działaczy niepodległościowych i socjalistycznych; 5) bojowników o wolność i działaczy zasłużonych dla historii regionu; 6) twórców kultury polskiej: pisarzy, poetów, kompozytorów, malarzy, grafików; 7) doniosłe wydarzenia, fakty historyczne i święta narodowe; 8) wydarzenia i fakty związane z utrwalaniem władzy ludowej; 9) nazwy odwołujące się do przyjaźni polsko-radzieckiej. Dobór patronów ulic poprzez symboliczne treści, jakie się za tym kryły, odgrywał znaczącą rolę dla umacniania polskości nowo przyłączonych terenów z jednej strony oraz legitymizowania nowej władzy z drugiej. W wielu wypadkach przywracano nazwy tradycyjne, sprzed 1933 r. Część nazw powstała w wyniku tłumaczenia nazw niemieckich (zwłaszcza w centrum miasta); były to na ogół nazwy wywodzące się od zawodów, a także nazwy związane z topografią terenu bądź z nazwami innych miejscowości.

Z analizy materiałów wynika, iż większość ulic otrzymała polskie brzmienie na Ziemiach Zachodnich i Północnych już w pierwszym etapie ich przemianowania na tych terenach, tzn. do końca 1946 r.; choć w małych miejscowościach szybciej uporano się z tym problemem (w niektórych przypadkach nawet w 1945 r.); druga fala nadawania imiennictwa polskiego zakończyła się w zasadzie jesienią $1947 \mathrm{r}$., aczkolwiek w dużych aglomeracjach (np. Gdańsk) proces ten trwał jeszcze w latach 1948-1949. Na podkreślenie zasługuje fakt, iż w tym okresie dochodziło niejednokrotnie do powtórnej (czasami nawet kilkakrotnej) zmiany nazewnictwa ulic. Świadczy to o tym, jak wielką rolę odgrywa nazwa w przestrzeni publicznej miasta i jak wielką wagę przywiązuje lokalna społeczność do przekazu, jaki się za nią kryje. 


\section{Bibliografia}

Antkowiak Z., Patroni ulic Wrocławia, Wrocław 1982

Antkowiak Z., Stare i nowe osiedla Wrocławia, Wrocław 1973

Antkowiak Z., Ulice i place Wrocławia, Wrocław 1970

Belchnerowska A., Białecki T., Toponimia miasta Szczecina, Szczecin 1988

Białecki T., Nazewnictwo geograficzne miasta Szczecina, Szczecin 1970

Białecki T., Zmiany w nazewnictwie geograficznym Szczecina po 1945 roku, Szczecin 1995

Białecki T., Zmiany topograficzne i onomastyczne Starego Miasta w Szczecinie na przestrzeni dziejów, „Przegląd Zachodniopomorski”, nr 3 (1986)

Biolik M., Typy semantyczne współczesnych nazw ulic i placów Olsztyna, „Komunikaty Mazursko-Warmińskie", nr 1-2 (1982)

Chludziński A., Nazwy ulic Białogardu, część I: A-Ó, „Przegląd Zachodniopomorski”, z 4 (2003)

Chludziński A., Nazwy ulic Białogardu, część II: P-Ż, „Przegląd Zachodniopomorski”, z. 1 (2004)

Choroś M., Jarczak Ł., Ludzie i historia w nazwach ulic Opola, Opole 2010

Domański J., Nazwy miejscowe dzisiejszego Wrocławia i dawnego okręgu wrocławskiego, Warszawa 1967

Engler W., Słownik nazw ulic Elbląga, Elbląg 2008

Jarczak Ł., O powojennych zmianach nazw ulic w Opolu, Opole 2007

Juniszewski J.M., Nazwy ulic i placów Legnicy, Legnica 2000

Juraszek-Ryś I., Jak powstały nowe nazwy ulic w powojennej Zielonej Górze?, „Poznańskie Studia Polonistyczne. Seria Językoznawcza", t. 19 (2012), z. 1 (39)

Kędziora K., Nazewnictwo ulic Wrocławia w latach 1945-1994, Wrocław 2012

Kobel E., Patroni wrocławskich ulic, placów i zaułków, Wrocław 2008

Nazwy ulic Wrocławia, red. B. Jancewicz, L. Smołka, Wrocław 2000

Kruszewski T., Niemiecko-polski spis ulic, placów i mostów Wrocławia 1873-1993, Wrocław 1993

Kruszewski T., Richard Wagner i jego opery w nazwach ulic Berlina i Wrocławia, Wrocław 2008

Kruszewski T., Zmiany nazw ulic we Wrocławiu w latach Trzeciej Rzeszy, Wrocław 1996

Łobodzińska R., Nazwy ulic Wrocławia z perspektywy prac Komisji Nazewnictwa Ulic TMW, [w:] Przeszłość, teraźniejszość i przyszłość polskiej onomastyki, red. R. Łobodzińska, Wrocław 2003

Myszkiewicz W., Ulice Zielonej Góry, [w:] Wokół niemieckiego dziedzictwa kulturowego na Ziemiach Zachodnich i Północnych, red. Z. Mazur, Poznań 1997

Nieckula F., Niech nazwy mówiq!!, [w:] Nazwy ulic Wrocławia, red. B. Jancewicz, L. Smołka, Wrocław 2000

Okólska H., Władze miejskie Wrocławia w latach 1945-1948, Wrocław 2005

Pawlikowska-Piechotka A., Nazwy ulic i placów - dziedzictwo kulturowe i dokument historii (na przykładzie Żoliborza urzędniczego w Warszawie, 1916-1995), „Ochrona Zabytków”, t. 49 (1996), nr 4 (195)

Piechocki S., Alfabetyczny spis niemieckich i polskich nazw ulic, placów oraz mostów Olsztyna, [w:] A. Wakar, Olsztyn. Dzieje miasta, Olsztyn 1997

Ruszkiewicz B., Nazwy ulic Będzina, „Językoznawstwo. Zeszyty Naukowe Wyższej Szkoły Pedagogicznej im. Powstańców Śląskich w Opolu", t. XI (1988)

Taszycki W., Nazwy wrocławskich dzielnic i przedmieść, [w:] Rozprawy i studia polonistyczne, t. 1, Wrocław-Warszawa-Kraków 1958

Wakar A., Olsztyn. Dzieje miasta, Olsztyn 1997 


\section{Netografia}

Barriga T., Mickiewicz zamiast Hitlera, Chrobry za Bismarcka. Wrocławskie ulice i ich nazwy, http:// www.tvn24.pl/wroclaw,44/mickiewicz-zamiast-hitlera-chrobry-za-bismarcka-wroclawskie-ulice-iich-nazwy,329729.html

Daniluk J., Oswajanie miasta. O zmianach nazw ulic w powojennym Gdańsku, http://historia.trojmiasto.pl/Oswajanie-miasta-O-zmianach-nazw-ulic-w-powojennym-Gdansku-n101787.html

Dawne nazwy ulic gdańskich, http://www.danzig-online.pl/nazwy/uliced.html

Jankowska M., Administracyjno-prawna problematyka zmiany nazewnictwa ulic Wrocławia w latach 1945-1946, s. 85, http://www.bibliotekacyfrowa.pl/Content/42784/02_Marta_Jankowska.pdf

Helmich M., Kujawinski J., Kutschke M., Toman J., „Odniemczanie” i polonizacja czyli z niemieckiego Breslau powstaje polski Wrocław, [w:] Polski Wrocław jako metropolia europejska - Pamięć i polityka historyczna z punktu widzenia oral history, red. Ph. Ther, https://homepage.univie.ac.at/philipp.ther/ breslau/html/odniemczanie.html

Kasprzyk B., Kędziora K. „Nazewnictwo ulic Wrocławia w latach 1945-1994”, https://histmag.org/Kamila-Kedziora-Nazewnictwo-ulic-Wroclawia-w-latach-1945-1994-recenzja-7261

„Komunikat władz Lęborka1946 dot. zmiany nazw ulic z niemieckich na polskie”, udostępnił P. Zbigniew Wołocznik, http://lebork.trim.pl/lauenburg-in-pommern/komunikat-wladz-leborka-1946-dotzmiany-nazw-ulic-z-niemieckich-na-polskie/

„Liegnitz. pl. Miejsca: Ulice, place”, oprac. M.Sz. Juniszewski, http://www.liegnitz.pl

Nazwy ulic miasta Massow do roku 1945 i Maszewa po roku 1945, https://www.maszewo.pl/informacje,gmina,ulice.html

Obrączka P., Jak nadawano bytomskim ulicom i placom polskie nazwy, http://zyciebytomskie.pl/index. php/ZB/arch_art/jak-nadawano-bytomskim-ulicom-i-placom-polskie-nazwy

Obecne i byłe nazwy ulic Mragowa, http://www.it.mragowo.pl/obecne-i-byle-nazwy-ulice-mragowa,3,2807,pl.html Polskie nazwy ulic Żarowa majq już 70 lat, http://www.izba.centrum.zarow.pl/ artykuly/454-polskie-nazwy-ulic-zarowa-maja-juz-70-lat

Raszkiewicz W.J., Nazwy ulic w Świdnicy, http://www.mojemiasto.swidnica.pl/?p=1151

Raszkiewicz W.J., Zestawienie nazw ulic niemieckich, http://www.mojemiasto.swidnica.pl/?p=1165

Rawa T., O nazwach reszelskich ulic, http://www.reszel.pl/nazwach_reszelskich_ulic,23,1014.html

Wałbrzych i okolice. Historia miasta na tle historii Dolnego Ślqska, rozdz. 8. (1933-1945), http:// blog.e-knapczyk.pl/walbrzych-i-okolice-historia-miasta-na-tle-historii-dolnego-slaska/rozdzial-viii-1933-1945/

Wykaz ulic w: Dawne nazwy ulic gdańskich, http://www.danzig-online.pl/nazwy/uliced.html

Zmiany nazw i placów w Łodzi, Historie Łódzkie, Łódzki portal historyczny, http://www.historialodzi. obraz.com.pl/zmiany-nazw-ulic-i-placow-w-lodzi/

Zmiany nazewnictwa będzińskich ulic, https://pl.wikipedia.org/wiki/Zmiany_nazewnictwa_b\%C4\% 99dzi\%C5\%84skich_ulic 


\section{Wokół zmian nazewnictwa ulic na Ziemiach Zachodnich i Północnych po 1945 r. - wybrane aspekty}

Streszczenie: Sytuacja na ziemiach zachodniej i północnej Polski była po 1945 r. szczególnie trudna z wielu względów; obszary te musiały jak najszybciej otrzymać nową tożsamość. Jednym z pilniejszych zadań było wówczas uregulowanie kwestii szeroko pojętego nazewnictwa miast, wsi, obiektów fizjograficznych, a także ulic. Proces nadawania polskiego brzmienia nazwom ulic przebiegał różnie w poszczególnych ośrodkach miejskich; inny wymiar miał w dużych aglomeracjach, a inny w mniejszych miejscowościach. W opracowaniu pokazano likwidowanie śladów niemczyzny w nazwach ulic i nadanie im polskiego imiennictwa na wybranych przykładach większych i mniejszych miast na terenie Ziem Zachodnich i Północnych (Wrocław, Gdańsk, Zielona Góra, Świdnica, Bytom, Legnica, Będzin, Reszel, Maszewo), aby zasygnalizować różne aspekty i cechy charakterystyczne tego zjawiska, a także trudności, jakie się z tym wiązały. Analiza przykładów przemianowań nazw ulic pozwala dostrzec pewne tendencje i kryteria, jakimi się wówczas kierowano (m.in. upamiętnianie ważnych z punktu widzenia historii, kultury i nauki polskiej postaci, a także bohaterów narodowych, bojowników o wolność narodu polskiego, polityków i działaczy niepodległościowych, jak również znaczących wydarzeń i faktów historycznych czy też związanych z utrwalaniem osiągnięć władzy ludowej etc.). Dobór patronów ulic, poprzez symboliczne treści, jakie się za tym kryły, odgrywał istotną rolę zarówno w umacnianiu polskości tych terenów, jak i legitymizowaniu nowej władzy. Większość ulic miejscowości na Ziemiach Zachodnich i Północnych otrzymała polskie nazwy do końca 1946 r.; drugi etap nadawania polskiego imiennictwa ulic zakończył się jesienią 1947 r.; natomiast w dużych aglomeracjach trwał jeszcze w latach 1948-1949. Niekiedy dochodziło do kilkakrotnej zmiany nazw ulic, co było podyktowane względami polityczno-ideologicznymi.

\section{On the changes of street names in the Western and Northern Territories after 1945 - selected aspects}

Abstract: The situation in the territories of western and northern Poland after 1945 was especially difficult for many reasons; in particular, because these areas had to be given a new identity as quickly as possible. One of the most urgent tasks at that time was the regulation of far-reaching issue of the naming of towns, villages, geographical entities and also streets. The process of giving a Polish timbre to street names proceeded differently in individual town centres. The extent of the issue was different in large agglomerations and smaller townships. This study shows the liquidation of traces of Germanness in street names and their acquisition of Polish names. This is achieved on the basis of selected examples from the largest and smallest towns and cities in the Western and Northern Territories (Wrocław, Gdańsk, Zielona Góra, Świdnica, Bytom, Legnica, Będzin, Reszel and Maszewo). These examples highlight different aspects and characteristics of this phenomenon, and also the difficulties connected with it. The analysis of examples of the renaming of streets enables the identification 
of certain tendencies and criteria which were in play at that time (e.g. memorialisation of people important to Polish history, culture and science and also national heroes, campaigners for the freedom of the Polish nation, politicians and independence activists, and also important historical events and facts, including those connected with the perpetuation of the achievements of the communist authorities). The range of street patrons and the symbolic meaning they contained played an important role not only in the strengthening of the Polishness of these territories but also in the legitimisation of the new authorities. The majority of street in the towns of the Western and Northern Lands had received Polish names by the end of 1946. The second stage of the Polonisation of street names ended in Autumn 1947. However, in large agglomerations this process was still ongoing in the years 1948-1949. Sometimes the names of streets were changed several times. This was dictated by politico-ideological concenrs.

Słowa kluczowe: nazwy ulic, Ziemie Zachodnie i Północne, zmiana nazewnictwa ulic po $1945 \mathrm{r}$.

Key words: street names, Western and Northern Territories, changes to street names after 1945 